\title{
From Chaotic to Order: Using Chaos Game in Mathematics Teaching
}

\author{
Fatih Karakuş ${ }^{\mathrm{a}}$ and Adnan Baki ${ }^{\mathrm{b}}$ \\ ${ }^{a}$ Sivas Cumhuriyet University, Education Faculty, Sivas/Turkey (ORCID: 0000-0001-9581-520X) \\ ${ }^{\mathbf{b}}$ Trazon University, Fatih Faculty of Education, Trabzon/Turkey (ORCID: 0000-0002-1331-053X)
}

Article History: Received: 17 March 2019; Accepted: 14 January 2020; Published online: 7 October 2020

\begin{abstract}
Mathematics has a structure based on concepts and operations with a certain and logical order. The discovery of this order is one of the basic elements of doing meaningful mathematics. It is very important to prepare learning environment that allow students to connect and build relationships between mathematical concepts. In this study, "chaos game" which will enable students to build relations among patterns, probability, series and limits has been introduced in detail in the process of obtaining from irregular cases to regular cases. The Chaos game was explained in detail with examples and given some explanations on why the regular shapes formed at the end of the game. Moreover, some tasks that students will be able to use their abilities such as hypothesis, mathematical connections and deduction and to make connection among some mathematical concepts such as probability, measure, patterns and numbers were formed. Reflections from students about these tasks were also included. In this context, the tasks were applied to 44 freshman students who were attending the department of elementary mathematics education in an education faculty of a state university in Central Anatolia region and some reflections from these tasks were examined. Findings showed that the tasks enabled students to use their skills such as hypothesis, observation, mathematical connections and deduction. It was also determined that the tasks enabled students to make practice on some mathematical topics such as measurement, exponential numbers, probability and patterns.
\end{abstract}

Keywords: Chaos game, fractal, mathematical task, reflections from the classroom

DOI:10.16949/turkbilmat.541136

Öz: Matematik belli bir düzen ve mantıksal sıralamaya sahip kavram ve işlemler üzerine kurulu bir yapıya sahiptir. Bu düzenin keşfedilmesi öğrencilerin anlamlı matematik yapmalarının temel unsurlarından biridir. Öğrencilerin anlamlı matematiksel ilişkileri görmelerine ve oluşturmalarına imkân verecek ortamların hazırlanması oldukça önemlidir. Bu çalışmada düzensiz olarak görülen bir durumdan düzenli geometrik şekillerin elde edilmesi sürecinde öğrencilerin örüntüler, olasılık, geometrik dizi ve seriler ile limit kavramları arasında ilişkiler kurmasını sağlayacak "Kaos oyunu" detaylı bir şekilde tanıtılmıştır. Kaos oyunu ve bu oyunun sonunda niçin düzenli şekillerin oluştuğu ayrıntılı bir şekilde incelenmiş ve örneklerle açıklanmaya çalıșılmıștır. Bunun yanında öğrencilerin hipotez kurma, ilişkilendirme, çıkarım yapma gibi becerilerini işe koşacağ 1 ve olasılık, ölçme, örüntüler ve sayı dizileri gibi matematiksel kavramlar arasında ilişkiler kuracağı etkinlikler geliştirilmiş ve bu etkinliklere yönelik öğrencilerden yansımalara yer verilmiştir. Bu bağlamda ülkemizin İç Anadolu bölgesinde yer alan bir eğitim fakültesinde öğrenim gören 44 ilköğretim matematik öğretmenliği öğrencisine geliştirilen etkinlikler uygulanmıştır. Elde edilen sonuçlar etkinliklerin öğrencilerin hipotez kurma, gözlem yapma, ilişkilendirme ve çıkarım yapma gibi becerilerini kullanmalarına imkan verdiğini göstermektedir. Bunun yanında etkinliklerin öğrencilerin matematiğin ölçme, üslü sayılar, olasılık ve örüntüler konularında uygulamalar yapmalarını sağladığı tespit edilmiştir.

Anahtar Kelimeler: Kaos oyunu, fraktal, matematik etkinliği, sınıf ortamından yansımalar

Türkçe sürüm için tıklayınız

\section{Introduction}

The constructivist approach emphasizes the learner building connections among their prior and new ideas in the process of constructing their own knowledge. According to this approach, the greater the number of connections among prior and new ideas, the better the understanding (Baki, 2008). Skemp (1976) defined understanding as a measure of quality and quantity of connections that a new idea has with existing ideas. He divides understanding into two parts: relational understanding and instrumental understanding. Skemp (1976) defines instrumental understanding as knowledge of rules and procedures used in applying mathematical process without knowing the reasons. For example, students know that $6 / 10$ can be simplified to $3 / 5$. Moreover, they know that $6 / 10$ is equivalent to $3 / 5$, but not understand that $6 / 10$ and $3 / 5$ indicate the same quantities. Skemp (1976) also defines relational understanding as knowing what to do and why in carrying out mathematical process. Relational understanding comprises when the student realizes the properties of mathematical concepts and build connections among these properties and other mathematical concepts in his/her mind. For example, when a student classifies that the square is also a rectangle and the rectangle is also a trapezoid and the parallelogram is also a trapezoid, it indicates that he/she has relational understanding. 
Teaching, lacking in relational understanding, causes generally negative attitude and misconceptions for mathematics among students (Van De Walle, Karp \& Bay-Williams, 2012). Connection has a key role in the learning of mathematical concepts and it is also one of the basic skills in teaching mathematical concepts (National Council of Teachers of Mathematics [NCTM], 2000). Activities, materials, examples and explanations used by the teacher in the teaching environment have a great role in gaining this skill. For this reason, it is very important to design environments where students can see interrelated relationships about a concept. The objectives to be created for such environments and to be brought to the students are set out in the curriculum. The deficiencies in the curriculum and the developments required by the era cause the renewal and changes in the programs from time to time.

In Turkey, the most radical reform movement in mathematics education programs has been in 2005 (Baki, 2008). As a result of the reform movement in 2005, the understanding adopted for learning and teaching mathematics has changed and the understanding that knowledge is an active product of the individual and knowledge is not independent from the individual has been accepted (Baki, 2008). In the mathematics education programs created during this period, it was emphasized that the topics were related to real life, and that students created their own knowledge based on concrete experiences and intuition (Ministry of National Education [MoNE], 2007). In line with the new understanding adopted in the curriculum, changes have been made in the topics included in the curricula. For example, for the first time in 2005 elementary mathematics curriculum, fractal geometry, a geometry different from Euclidean geometry, was included (MoNE, 2007). Fractal comes from the Latin verb "frangere", which means "irregular, broken, complex" (Manbelbrot, 1982). Intuitively, fractals are symmetric shapes with respect to magnification (Fraboni \& Moller, 2008). More mathematically, a fractal is defined as a shape which has the property of self-similarity- that is it consists of smaller copies of itself with magnification (Karakuş \& Baki, 2011). In elementary mathematics curriculum, the activities of building fractals as a result of recursive iteration were included. Fractals were also in 2010 secondary school mathematics curriculum (MEB, 2010). In this curriculum, fractals were built by using transformations which were reflection, translation and rotation and finding various patterns in these shapes (Karakuş \& Baki, 2011). Thus, by using fractal geometry in both elementary and secondary school mathematics curriculums, it was tried to help students to make a relationship between geometry and real life and to discover similarities and differences with Euclidean geometry by examining different geometries. Similarly, NCTM (1991) suggests that fractals should be included in mathematics curriculum and that students' attitude and interest can be increased and students can make relationships between mathematics and nature. The fact that fractals can be constructed both geometrically and algebraically shows that they are a good application for studying the relationships between geometry and other areas of mathematics. However, in line with the updates made in mathematics curriculums, fractals were not included in both 2013 and 2017 mathematics curriculums. Although fractals are not a learning outcome in existing mathematics curriculums, they have great importance in discovering many mathematical features and employing different mathematical information in this discovery process. In the literature, it is stated that fractals help students to make different relationships both with the concepts in mathematics and with other disciplines and nature (Adams \& Aslan-Tutak, 2006; Bolte, 2002; Devaney, 2004; Fraboni \& Moller, 2008; Naylor, 1999; Siegrist, Dover \& Piccolino, 2009; Vacc, 1999). For example, Fraboni and Moller (2008) state that students can establish relationships between different subjects of mathematics and make various discoveries while examining the Sierpinski triangle and its properties. Sierpinski triangle (Figure 1) can be constructed by using following steps:

1. Start with an equilateral triangle

2. Subdivide it into four smaller congruent equilateral triangles and remove the central triangle

3. Repeat step 2 with each of the remaining smaller triangles infinitely.

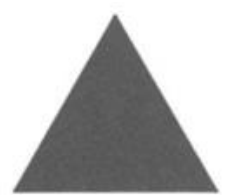

Initial

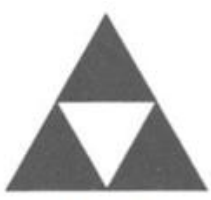

Step 1

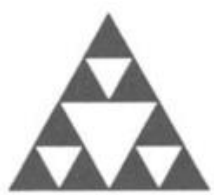

Step 2

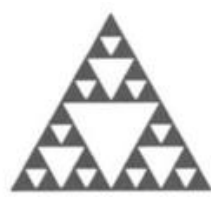

Step 3

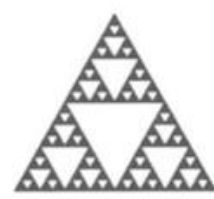

Step 4

Figure 1. The evolution of Sierpinski triangle

Fraboni and Moller (2008) state that a discovery made by students with the Sierpinski triangle may be in the form of new triangles that occur at each iteration step, and determine the relationship between them and the original triangle. In order to determine this relationship, students should use the information "line joining the mid-points of two sides of a triangle is parallel to the third side and equal to half the length of the third side" (Fraboni \& Moller, 2008, p. 198). With this information, they will be able to see that the triangles formed in each iteration step are equal and the triangles formed in the previous iteration step are similar to the original triangle. Thus, while students make discoveries about the Sierpinski triangle, they also make relationships for their 
knowledge of equality, similarity, parallelism and mid-point theorem "line joining the mid-points of two sides of a triangle is parallel to the third side and equal to half the length of the third side". Similarly, Naylor (1999) gave an activity in calculating the perimeter and area of the Sierpinski triangle. Naylor (1999) states that a number pattern in the form of the powers of 3 can be obtained (for the first step is 1 , for second step is 3 , for third step is $3^{2}=9$, for forth step is $3^{3}=27$, etc.) for the number of triangles removed while the Sierpinski triangle is formed. A similar pattern can be obtained for small black triangles formed at each iteration step. In addition, the perimeter of the Sierpinski triangle can be expressed by a divergent sequence of $3\left(1+3 / 2+(3 / 2)^{2}+(3 / 2)^{3}+\cdots+(3 / 2)^{\mathrm{n}}\right)$. Since this sequence is divergent, the perimeter of the Sierpinski triangle goes to infinity. In contrast, the area of the Sierpinski triangle converges to zero. This activity shows that students make use of number patterns, exponential numbers, sequences and limit concepts when calculating the perimeter and area of the Sierpinski triangle. In addition, the shapes in Euclidean geometry have a static structure. In other words, Euclidean shapes have a certain perimeter and area. On the other hand, the Sierpinski triangle has an infinite increasing perimeter and also an area approaching towards zero. Such extraordinary situations not only attract students 'attention but also raise questions such as "how can a shape be an infinitive perimeter with zero area?" or "Could there be other shapes like this?"

\subsection{What is Chaos Game?}

As in the studies of Fraboni and Moller (2008) and Naylor (1999), fractals are often created as a result of regular iterations. However, fractals can be created with the help of randomly situations. One of these situations that construct a fractal is chaos game. Chaos game is a game that allows students to see that certain patterns and relationships can be found in many situations randomly expressed in their environment. The rule of the game is very simple: Start with three point such as $\mathrm{A}, \mathrm{B}$ and $\mathrm{C}$ at the vertices of an equilateral triangle and pick any point whatsoever in the triangle; this point is $z_{0}$ called the seed. Now roll the die. Depending upon which numbers come up, move the seed half the distance to the similarly numbered vertex. The game is played as follows:

Roll the die, if the numbers 1 or 2 come up move the seed half distance to vertex A.

Roll the die, if the numbers 3 or 4 come up move the seed half distance to vertex B.

Roll the die, if the numbers 5 or 6 come up move the seed half distance to vertex C.

Repeat this procedure, each time moving the previous point half the distance to the vertex whose number turns up when the die is rolled. For three steps, the game can be played as follows: pick any point whatsoever in the triangle with the $\mathrm{A}, \mathrm{B}$ and $\mathrm{C}$ at vertices. Roll the dice and if 3 comes up, then move the $\mathrm{z}_{0}$ seed half the distance to the $\mathrm{B}$ vertex. Mark this point as $\mathrm{z}_{1}$ and this point is the new seed. Roll the die again and 1 comes up, then move the $z_{1}$ seed half distance to the A vertex. Mark this point as $z_{2}$ and this point is the new seed. Roll the die again and 6 comes up, then move the $z_{2}$ seed half distance to the $C$ vertex. Mark this point as $z_{3}$ (Figure 2).

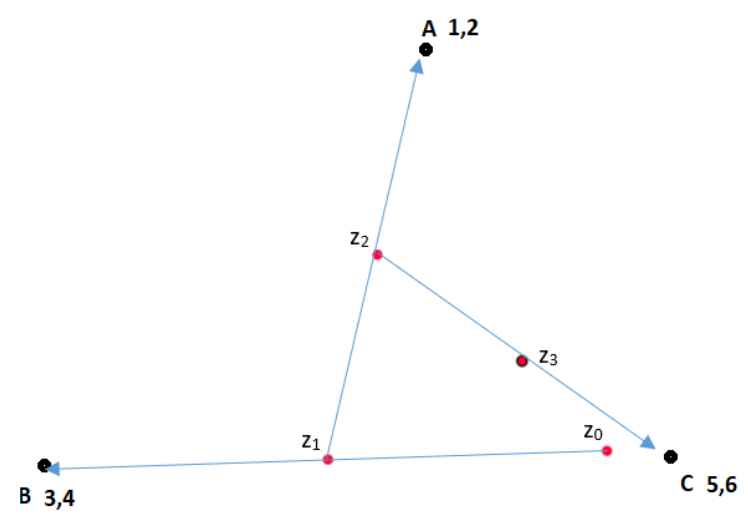

Figure 2. Orbit of seed in the Chaos Game

Roll the die again and again a sequence of infinite points such as $z_{0}, z_{1}, z_{2}, z_{3}, \ldots$ is obtained. The following questions may come to mind about this sequence of points:

- Is the repetition process that creates the dots really random?

- Roll the die many hundreds of times and what will be the resulting pattern of points?

Since, when the dice is rolled, the probability of the numbers matched with the corner points is equal, the iteration process that allows the formation of dots in the game of chaos is random. In addition, the location of the first seed is also random.

As described above, what kind of shape will emerge when the chaos game is played is quite interesting. As a result of the randomness of the game and the sequence of dots behaving randomly, it may be thought the 
resulting image will be a random smear of points or the points will eventually fill the entire triangle. Below are the figures formed by different number of iteration in the Chaos Game (Figure 3).
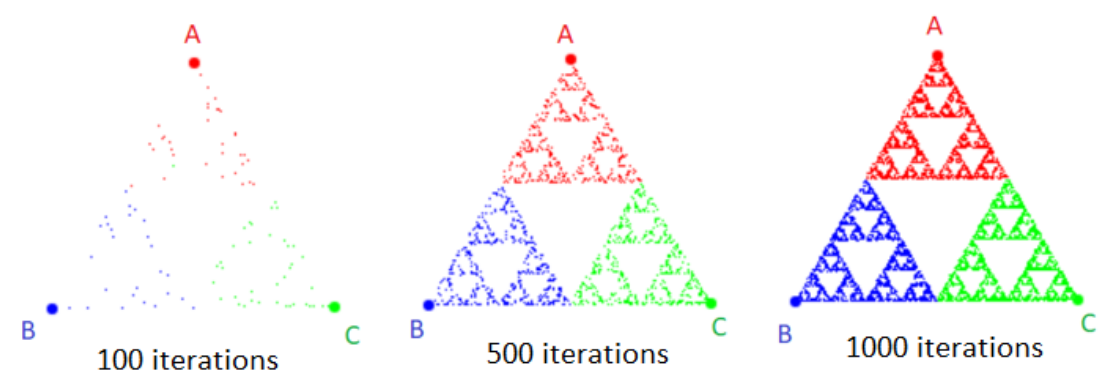

Figure 3. Figures formed in different iterations in Chaos Game

According to Figure 3, as the number of repetitions increases, resulting figure is Sierpinski triangle. This is quite unusual and interesting. Because a random geometric result emerges as a result of a random situation.

\subsection{Why does the Sierpinski triangle arise from the chaos game?}

When playing the chaos game, a starting point "seed" is picked. Suppose that the seed $\mathrm{z}_{0}$ is in the middle of triangle $\mathrm{ABC}$. When roll the die, the new seed $\mathrm{z}_{1}$ will be in the half distance between the $\mathrm{z}_{0}$ and one of the three corner points. Suppose, roll the die and 6 comes up. In this case, the $\mathrm{z}_{1}$ seed close to $\mathrm{C}$ vertex and would be in the middle of the 3 small triangles formed in the first iteration of the Sierpinski triangle (Figure 4).
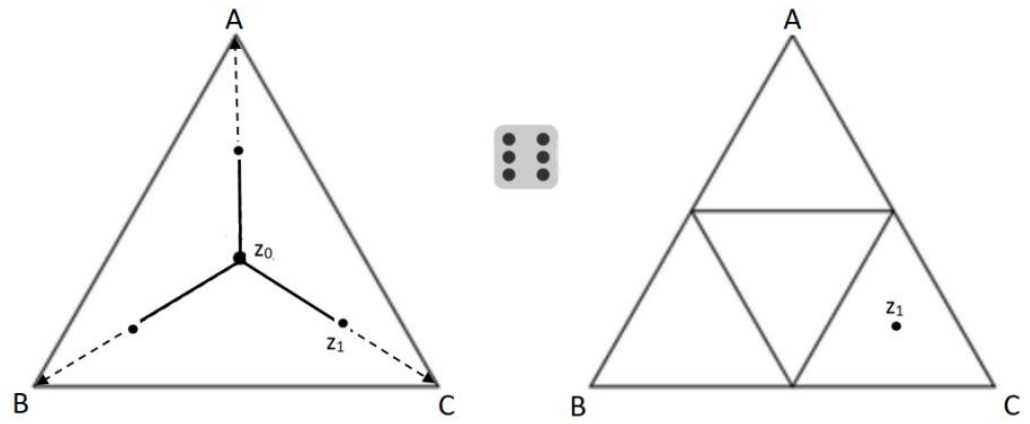

Figure 4. Location of $\mathrm{z}_{1}$ seed in the Chaos Game.

Similarly, the new seed $\mathrm{z}_{2}$ will be in the half distance between the $\mathrm{z}_{1}$ and one of the three corner points. Suppose, roll the die and 4 comes up. In this case, the $\mathrm{z}_{2}$ seed close to B vertex and would be in the middle of the 9 small triangles formed in the second iteration of the Sierpinski triangle (Figure 5).
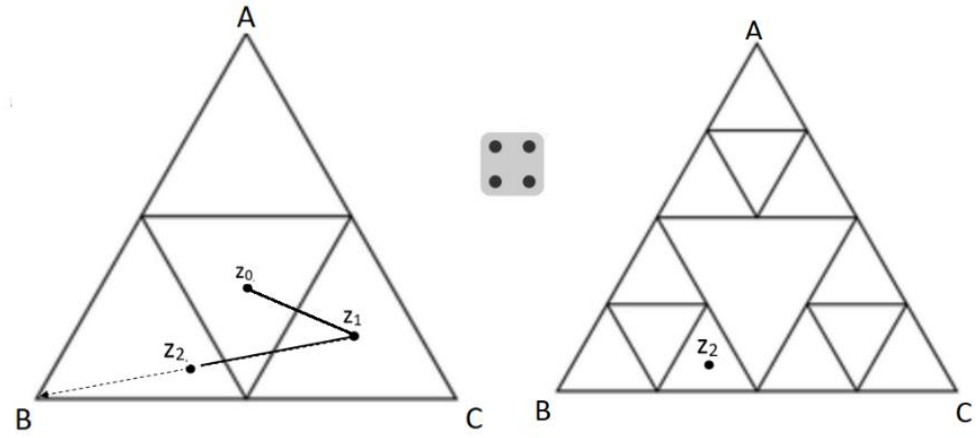

Figure 5. Location of $\mathrm{z}_{2}$ seed in the Chaos Game

Again play the game, the new seed $z_{3}$ will be in the half distance between the $z_{2}$ and one of the three corner points. Suppose, roll the die and 1 comes up. In this case, the $z_{3}$ seed close to A vertex and would be in the middle of the 27 small triangles formed in the third iteration of the Sierpinski triangle (Figure 6). 

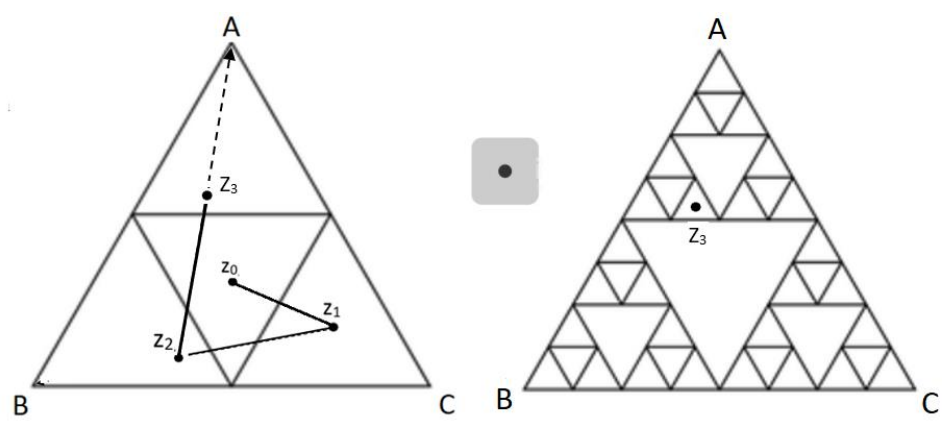

Figure 6. Location of $\mathrm{z}_{3}$ seed in the Chaos Game

Similarly, the new seed $\mathrm{z}_{4}$ will be in the middle of the 81 small triangles formed in the third iteration of the Sierpinski triangle. Thus, the $z_{1}, z_{2}, z_{3}, \ldots$ points will be in the triangles formed in the different iteration of the Sierpinski triangle. The points will lie smaller triangles and these triangles very quickly become microscopic in size. So, the orbit looks like it lies on Sierpinski triangle.

Chaos game which will enable students to build relations among patterns, probability, series and limits has been introduced in detail in the process of obtaining from irregular cases to regular cases (Devaney, 2004). The purpose of this study was to prepare tasks in which students build relations among mathematical concepts and to give reflections from the implementation of these activities. The problems of this study were as follows:

- What are the reflections from students about tasks?

- When the tasks were implemented, what kind of mathematical relationships do the students build?

The Chaos game was explained in detail with examples and given some explanations on why the regular shapes formed at the end of the game. Moreover, some tasks that students will be able to use their abilities such as hypothesis, mathematical connections and deduction and to make connection among some mathematical concepts such as probability, measure, patterns and numbers were formed. In this context, the tasks were applied to students and some reflections from these tasks were examined.

\section{Method}

The research methodology of this study was a case study, since students design activities that will create different associations between mathematical concepts in chaos and examine the associations of elementary school mathematics freshmen students towards these activities. Case studies give the researcher the opportunity to describe the special cases examined with a special focus on a very specific subject or situation, and to explain the cause-effect relationships between the variables (McMillan \& Schumacher, 2014).

\subsection{Sample}

The sample of this study has been determined by convenience sampling, which is one of the non-random sampling methods. The reason for choosing the convenience sampling method in the study is that the group to be examined is accessible and practicable due to the limitations in terms of time, money and labor (McMillan \& Schumacher, 2014). The participants of this study consisted of 44 freshman students who were attending department of elementary mathematics education in an education faculty of a state university in Central Anatolia region. 36 of these students are women and 8 are men. None of the students have any prior knowledge of the chaos game.

\subsection{Data Collection}

Data were collected from students' written explanations and focus group interviews. Three tasks were formed for chaos game. The aim of the first task was to ensure that students can recognize regular shapes formed at the end of a random process. Thus, students will be created an understanding on chaos and chaotic thinking. The aim of the second task was to make a connection between chaos game and Sierpinski triangle. The aim of the last task was about the probability of the roll a die and construction of Sierpinski triangle. The tasks were prepared taking into account the development steps of a task in the study of Baki (2008). After the tasks were prepared, these tasks were presented to the two academics who were expert about fractals and also completed their doctoral education in the field of mathematics education. Experts have stated that the tasks are generally appropriate, but some minor corrections can be made. For example, it was stated that it would be more appropriate for students to enter their own values in addition to the probability values given in task 3 . For this purpose, a place is reserved for students to write and examine their own values under the probability values given in task 3. According to the opinions of the experts, the final arrangements were made in the activities and application started. Before applying the tasks, students were separated into eleven groups and each group consists of four students. During the implementation of the tasks, each group was asked to fill in the activity sheets in line with the guidelines and explain the reasons for the results they obtained. In the second stage of data 
collection, focus group interviews were conducted with 16 students in 4 groups who participated in the study and volunteered. The purpose of the focus group discussion is to reveal the thoughts of the students that do not appear on the activity sheets, to examine the reasons of the answers they have given and to discuss their answers. The focus of the group discussions is the answers given by the students to the activities. Therefore, the students were asked questions such as, "How did you get this result?", "What did you observe?", "Why did you write this answer?". The aims of the questions are to reveal what kind of thinking processes students have. Focus group interviews were recorded on audio and each interview lasted an average of 30 minutes.

\subsection{Implementation of the tasks}

Before applying the tasks, students were separated into eleven groups and each group consists of four students. While the students were doing the activities as a group work, one of the researchers guided the students by walking between the groups, with clue questions and guidance when the students had difficulties. The researcher who carried out the application is a mathematics educator experienced in fractals. The researcher has many studies in national and international refereed journals about fractals and teaching fractals. The activities were carried out for a total of 4 class hours, 2 class hours per week, for 2 weeks. In the implementation of the activities, a computer laboratory was used and a computer connected to the internet was given to each group. The first activity lasted two hours and students played chaos game with the help of transparent paper and pencil. The reason for playing the game in this way is to make students realize that the movement of the dots is random and the probability of rolling dice is equal. In addition, it is aimed to develop skills such as hypothesis, observation and inference about what kind of shapes will be formed at the end of the game. After playing the game on paper, the students were asked to turn on the computers and they were allowed to play the game on the website http://www.shodor.org/interactivate/activities/TheChaosGame/. Since the website allows more points to be formed in a short time, it provides a more accurate Sierpinski triangle. The second activity lasted one hour and the students were aimed to establish a relationship between the Chaos game and the Sierpinski triangle and to realize how the Sierpinski triangle formed as a result of the movements of the points in the game. In this activity, students are expected to use their skills such as pattern finding, prediction and inference. The last activity lasted 1 lesson and once more http://www.shodor.org/interactivate/activities/TheChaosGame/ website was used. In this activity, different probability states of the numbers in the dice were written in the program on the website and the students observed the shapes that occurred in each probability case and the activity also aimed to determine the conditions of the formation of the Sierpinski triangle as a result of these observations.

\subsection{Data analysis}

Students' explanations for each task were compared and they divided into two categories as right explanations and wrong explanations. Then, each category was examined in its own way and the reflections from the experiences of the students were presented descriptively. For this purpose, direct quotations were excerpted from the explanations of students. The data obtained from the focus group interviews were presented descriptively to support the responses of the students to the tasks. In order to ensure the internal validity, the control of the data obtained from the focus group interviews was done with participant confirmation (Fraenkel \& Wallen, 2011). In addition, data triangulations (Cohen, Manion \& Morrison, 2000) was made using both the responses to the activities and the data obtained from the focus group interviews. To ensure external validity, quotations from students' answers and focus group interviews are included in the findings section.

\section{Findings}

\subsection{Reflections from the "Chaos Game"}

This activity is designed to enable students to see that regular shapes can occur at the end of a random process, thereby creating an understanding of chaotic thinking. While the first part of the activity was held in paper-pencil environment, the second part was held in computer environment. Playing the game primarily in paper-pencil environment helps students both see the movement of the dots and realize that the process is random. The randomization of the starting point in the chaos game and the randomness of the numbers in the dice throw causes a perception that a triangle consisting of random points may be formed at the end of the process. At the beginning of the activity all groups stated that, a triangle covered with dots will be formed as a result of the game. For instance, the findings from the focus group interview with Group 1 are presented below:

Researcher: In the beginning, when you were playing the game, what kind of shape did you think would occur?

Group 1: We thought that a triangle would be formed which was not completely clear.

Researcher: Why did you think such a shape would occur?

Group1: We marked a random point between points A, B, C. Since we do not know what the number from the dice will be, we first thought that a random shape would be formed. Then we saw that no point overlapped, and all the points remained inside. Therefore, we thought that a triangle filled with dots would form. 
When groups put the markings they made on transparent papers (see Figure 7) on top of each other and combined them, they obtained the observations in Table 1.

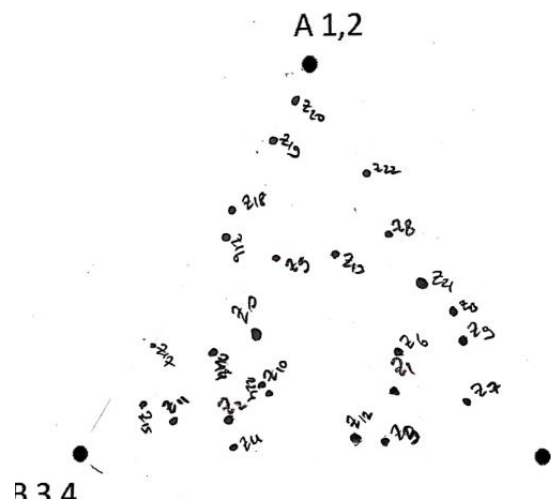

\section{5,6}

Figure 7. A student's markings for points in the chaos game

Table 1. Observations of the groups in the chaos game activity

\begin{tabular}{lc}
\hline Observations & f \\
\hline Too many points did not fall where the triangle's center of gravity is. & 3 \\
The points were concentrated in certain places instead of the middle of the triangle. & 4 \\
The middle of the triangle remained empty. & 8 \\
\hline
\end{tabular}

Table 1 shows that when the number of points in the game increases, some points decrease less in the inner region of the triangle and the points towards the edges are increased. For instance, the findings from the focus group interview with Group 1 are presented below.

Researcher: What did you observe when you add your papers up with your group friends?

Group1: It was not exactly obvious, but we noticed that there is a gap in the middle of the triangle. The points were not increased here.

Researcher: Where were the points increased?

Group1: The dots were clustered at the points that form the corners. There were gaps in certain places.

Researcher: Why may there be less points in the middle of the triangle?

Group1: We thought this as a group. Actually, we don't know why. However, it may be related to taking half of the distances each time.

Researcher: Why might it be about taking half of the distances?

Group1: The point we choose does not go out of the triangle and the points are getting closer to each other. The distance between the dots decreases with each roll of dice. This causes the points to accumulate in certain places. It may be because of this. I am not sure.

The explanations above show that the students realize that a triangle filled with dots will not occur at the end of the game and that there are gaps in some places. It is obvious that there are also inferences about the reasons for these gaps. When they played the game of Chaos on their website, they quickly observed that the Sierpinski triangle formed at the end of the game. In this context, the interview with Group 4 is presented below.

Researcher: What shape did you get when you played the game on the website?

Group 4: A fractal consisting of empty triangles was formed. You said your name, the Sierpinski triangle.

Researcher: What did you think when this shape occurred?

Group 4: It was very interesting. I never thought that such a shape would occur.

Researcher: Why might this fractal occur?

Group 4: I do not know the reason exactly. As we marked the dots on the paper, we saw the gap in the middle. But I had not guessed it would be this smooth. Maybe taking half the length may be the reason for this.

Researcher: What causes you to this thought?

Group 4: Looking at the shape carefully, there are intertwined triangles and they are all joined from the middle of their edges. We were also finding the midpoint of the dots in the game. We thought it might be from here.

The explanations above show that students observe that there may be a link between the rule of the game and the stages of the formation of the Sierpinski triangle. 


\subsection{Reflections from the activity for relationship between chaos game and Sierpinski triangle}

This activity is designed for students to determine the final location of the point using their reasoning skills and to establish a relationship between the steps of the formation of the Sierpinski triangle and the number of dice rolls. In the first part of the activity, 8 groups found a correct relationship between the formation steps of the Sierpinski triangle and the number of dice rolls, while 3 groups did not find a relationship. The relationship obtained by Group 3 is presented in Figure 8.

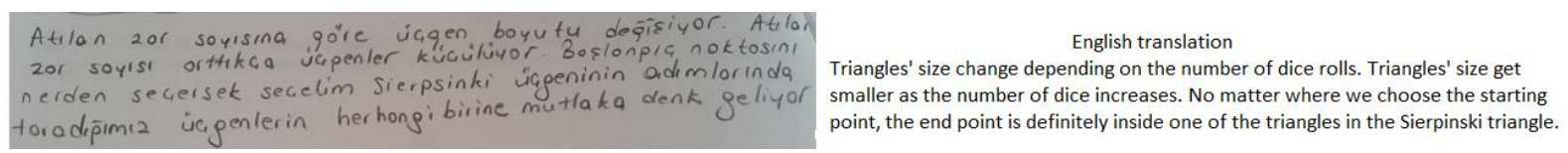

Figure 8. The relationship obtained by Group 3

In addition, there are groups that achieve different relationships. For instance, the relationship that Group 5 has achieved is presented in Figure 9.

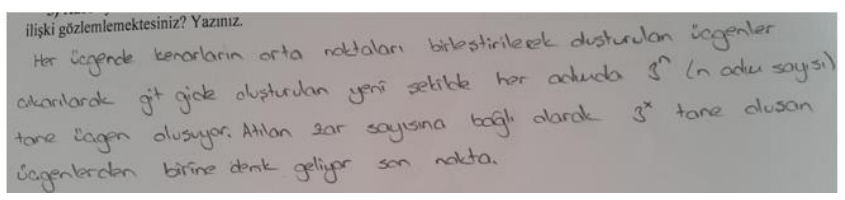

English translation

$3^{\wedge} \mathrm{n}$ ( $\mathrm{n}$ is step number) number of triangles are formed by removing the triangles created by connecting the midpoints of the sides. Depending on the number of dice rolls, the end point falls inside one of the $3^{\wedge} \mathrm{x}$ triangles

Figure 9. The relationship obtained by Group 5

In the second part of the activity, the students were expected to predict the dice that may come according to the last place where the point was found. The prediction of 10 groups were correct, and only the estimates of 1 group were incorrect. The interview with Group 4 which made the correct estimate is presented below:

Researcher: How did you determine the numbers on the dice?

Group 4: We tried to guess in reverse.

Researcher: Can you explain a little more? How?

Group 4: Since the end point is near corner B, we thought the dice rolled for the third time could be 3 or 4. Then the other point should be close to point A.

Researcher: Why? Why should it be close to point A.

Group 4: Otherwise, point 2 must fall outside the triangle, and our points are always inside the triangle.

Researcher: So point 2 cannot be close to $\mathrm{C}$.

Group 4: Yes. In the other case where we take the midpoint of the distance, the point falls out. In this case, the 2 nd dice may be 1 or 2 .

Researcher: What would the first dice be then?

Group 4: If we continue with the same logic, the first dice should be 5 or 6 , so the first point should be close to point $\mathrm{C}$.

From the statements above, it is clear that the students make informed predictions using the available data without measuring

\section{3. "Reflections from the "Chaos Game and Probability" activity}

The purpose of this activity is to enable students to realize that the probability of the numbers in the dice rolled in the Chaos game is equal and to determine in which cases the Sierpinski triangle is formed. All groups performing the activity determined that the formation of the Sierpinski triangle depends on the probability of the numbers on the dice. For instance, the interview with Group 7 is presented below.

Researcher: What relationship did you determine between the probability of the numbers on the dice and the Sierpinski triangle in the game of chaos?

Group 7: If we want to create the full triangle, the probability of the numbers coming to each corner must be the same. Otherwise, sometimes a full triangle does not occur.

Researcher: What kind of shape is formed?

Group 7: At the points where the probability is low, the parts of the triangle with the corners become less faint, indistinct, the other parts become clearer.

Researcher: Does a Sierpinski triangle still form?

Group 7: Yes, it is formed, but not every corner has the same clarity, some places are more faint

Researcher: Well, have you ever encountered a situation where the Sierpinski triangle does not occur?

Group 7: Yes, for example, when we make the probability 100 or 110 , the Sierpinski triangle does not occur. 
Researcher: What kind of shape is formed?

Group 7: In 100 all points are gathered on corner A. Since we always take half of the distance, if every time we throw 1 or 2 , the dots are getting closer to corner A and become like a single point. In 110 , a line segment is formed between corner A and B. The logic is the same.

Researcher: So what is the condition for the Sierpinski triangle to form/originate as a result of the Chaos game?

Group 7: The probability of all points is the same.

The expressions above show that students realize that the probability of the numbers on the dice must be equal to form the Sierpinski triangle in the Chaos game.

\section{Discussion, Conclusion and Suggestions}

In this article, we have described chaos game and provided some tasks for students. Chaos game as a different fractal building method were explained and gave reason for the relationship between Sierpinski triangle and Chaos game. In addition, examples were given from the implementation of the tasks. Students' experiments and reflections on the implementation of tasks were presented. Thus, the adequacy of the task was revealed.

The findings of this study indicated that most students used the observation and hypothesis abilities during the first task. The first activity was prepared for students to create perception about Chaos theory. In this activity, students are expected to realize that there may be a certain order in an event that is seen randomly. In this context, students often used their observation and hypothesis skills during the activity. The students also claimed that the shape that would appear due to the random selection of the starting point at the beginning of the game and the numbers that came in the dice roll could be a random shape. They gave some hypothesis like the final shape should be a filled triangle by dots at the end of the chaos game. However, their later observations caused these hypotheses to change. Their new claim has been that there is no point in the inner region or center of gravity of the triangle. In this context, it is clear that the first activity allows students to use their skills such as hypothesis, observation and inference. In addition, this activity has helped students to monitor the movement of points by measuring in a repetitive process and to make inferences at the end of this process. Play the chaos game on computer revealed that the randomly generated sequence of midpoints increasingly produces a highly structured fractal shape. As the random process was repeated, they noticed that the final shape must be the Sierpinski triangle. In the renewed mathematics curriculum, emphasis is placed on preparing environments and giving examples where students will use their skills such as hypothesis, observation, correlation and inference (MoNE, 2018a; 2018b). In addition, in studies conducted in the literature (Adams \& Aslan-Tutak, 2006; Bolte, 2002; Devaney, 2004; Fraboni \& Moller, 2008; Karakuş, 2015, 2016; Naylor, 1999; Siegrist et al., 2009; Vacc, 1999 ) it is stated that fractals help students to establish relationships between different subjects of mathematics such as similarity, logarithm, patterns and limit, and enables them to use their skills such as hypothesis, association and inference. The results obtained from this study are similar to the results of the studies in the literature. In the first activity, the Chaos game was played for only three points. This activity can be redesigned with a different number of points. In addition, at the end of the activity, questions can be added to students to form new claims and inferences, such as what kind of forms may occur if the game is played for a different number of points. Also, the game can be replayed for different ratios such as $1 / 3$ or $1 / 4$ instead of $1 / 2$ in the movement of the points. Activities involving these situations and reflections to be taken from students for these activities can be examined in future studies.

National Council of Teachers of Mathematics (NCTM, 2006) mentions the importance of students' recognition, creation and generalization of different patterns in the development of algebraic thinking. The second activity created in this study allows students to discover such patterns. Students made relationship between the number of sub-triangles and the number of the rolls of the die in the second task. Almost every group participating in the study has established correct relationships between the stages of formation of the Sierpinski triangle and the number of dice rolled. In addition, different patterns have emerged, such as the number of dice rolled and the number of triangles formed in the Sierpinski triangle. This shows that the activities designed have the potential to help students find different patterns. In addition, the second activity allows students to use their ability to make predictions and inferences, just as in the first activity. In particular, the section where the last place of the point is given and the place where it was initially asked, enables students to use these skills. In the literature (Adams \& Aslan-Tutak, 2006; Fraboni \& Moller, 2008; Naylor, 1999; Vacc, 1999; Karakuş, 2015), it is stated that students can reach different generalizations about the area or perimeter of the Sierpinski triangle by using exponent numbers, sequences and limit. In this context, the results obtained from this study coincide with the results of the studies conducted in the literature.

In the last task, students established a relationship between the probabilities of the die and construction of Sierpinski triangle. Findings showed that the tasks enabled students to use their abilities such as hypothesis, observation, mathematical connections and deduction. As a result of the activity, the students concluded that the Sierpinski triangle depends on the probability of numbers on dice which were equal probability. In addition, they 
had the opportunity to observe what shapes are formed in different probability and in what cases the Sierpinski triangle does not occur. Studies in the literature (Gürbüz, 2006; Işık \& Özdemir, 2014; Memnun, 2007) show that the use of concrete materials and worksheets in the teaching of probability topics has a positive effect on students' meaningful learning and academic achievement. The reflections obtained from the activities developed in this study show that activities can help students understand probability topics. In this context, the effects of the tasks on students' meaningful learning and academic success can be examined in future research.

The finding of this study is similar to the literature. It was also determined that the tasks enabled students to make practice on some mathematical topics such as measurement, exponential numbers, probability and patterns. The chaos game not only helps students to build Sierpinski triangle, but also provides a basis for dynamic systems and chaos theory. These tasks can enable students to show interest in or study with these concepts in their future lives. Fractal activities can be found in most NCTM Standards and mathematics curriculums. Thus, fractals can be taught separately or incorporated as examples into traditional lessons.

Chaos game does not only help students create the Sierpinski triangle. At the same time, it provides a foundation for students to realize that regular patterns will occur as a result of random situations, and thus it provides a basis for dynamic systems and chaos theory. In recent years, dynamic systems, fuzzy logic and chaotic structures are among the most frequently discussed topics in the field of mathematics. These prepared activities can allow students to show interest in or work with them in their future lives. Since one of the general objectives of mathematics education is raising future mathematicians (Baki, 2008). As a result of a random situation, the emergence of regular shapes will attract the attention of students at each grade level. Such activities will positively affect students' interests and attitudes towards the mathematics lesson. In the studies conducted in the literature (Ünlü, 2007; Yurtbakan, Aydoğdu-İskenderoğlu ve Sesli, 2016), it is emphasized that the activities and materials to be used in the course have an impact on students' interest in mathematics lesson. In this context, the effects of these designed activities on students' interests and attitudes towards mathematics lesson can be examined in future studies. Students working with the activities prepared in the study have the opportunity to establish relationships between many different mathematical concepts such as probability, number sequences, patterns and measurement. NCTM (2000) emphasizes the importance of working in environments with appropriate activities, materials and examples for students to learn mathematical concepts meaningfully. In this context, the activities prepared have the potential to make different associations between students' mathematical concepts.

In this study, the activities in which students will establish relations with patterns, probability, measurement and number sequences are included. In addition, the importance of integrating information and communication Technologies (ICT) into lessons in mathematics education programs is emphasized (MEB, 2018a; 2018b). Considering the teaching of mathematics in our country, it can be said that a traditional approach focused on teachers and the board is adopted (Baki, 2008). In the teaching of mathematics subjects, the rules and features related to the subjects are given by the presentation method, and the subjects are taught with the help of the drawings written on the blackboard. National Council of Teachers of Mathematics (NTCM, 200) emphasizes the importance of using concrete materials, drawings and information and communication technologies in school mathematics. In the activities designed in this study, web site applications prepared for teaching purposes are included. Thus, students were enabled to use technology while establishing these relationships. Thus, the activities designed in this context will contribute to the integration of ICTs into mathematics lessons. 


\section{Düzensizlikten Düzene: Kaos Oyununun Matematik Öğretiminde Kullanılması}

\section{Giris}

Yapılandırmacı yaklaşım öğrenenin kendi bilgisini inşa etmesi sürecinde mevcut bilgileri ile yeni bilgiler arasında bağlar kurmasını vurgulamaktadır. Bu yaklaşıma göre ne zaman ki yeni bilgiler eski bilgi ile uyumlu bir şekilde ilişkilendirilir, o zaman söz konusu kavramla ilgili anlama oluşmuş olur (Baki, 2008). Skemp (1976) anlamayı işlemsel anlama (instrumental understanding) ve ilişkisel anlama (relational understanding) olmak üzere ikiye ayırmıştır. Skemp (1976) işlemsel anlamayı gerekçelerini bilmeden kurallarla matematiksel işlemler yapma becerisi olarak tanımlamaktadır. Örneğin bir öğrenci 6/10 kesrini sadeleștirerek 3/5 kesrini elde edebilir. Ancak bu durum öğrencinin denk kesir kavramını ya da 6/10 ile 3/5 kesirlerinin aynı çokluğu temsil ettiğini bildiğini göstermez. Skemp (1976) ilişkisel anlamayı ise öğrencinin matematiksel bir işlemi yaparken ne yapıldığını ve neden yapıldığını bilmesini kapsayan bir anlama olarak tanımlamıştır. İlişkisel anlamanın gerçekleşmesi için öğrencinin zihninde matematiksel bir kavramı oluştururken o kavramla ilgili özellikleri fark etmesi ve bu özellikleri zihnindeki diğer matematiksel kavramlarla ilişkilendirmesi gerekir. Örneğin, bir öğrencinin karenin aynı zamanda bir dikdörtgen ve dikdörtgenin aynı zamanda paralelkenar ile paralelkenarın aynı zaman da bir yamuk olduğu şeklinde bir sınıflandırma yaparak kavramlar arasındaki ilişkileri ifade etmesi onun ilişkisel anlamaya sahip olduğunu gösterir.

Genelde ilişkisel anlamadan yoksun olarak yapılan öğretim matematiğin sevilmemesine ve öğrencilerde kavram yanılgılarının oluşmasına neden olmaktadır (Van De Walle, Karp ve Bay-Williams, 2012). Matematiksel kavramların anlamlı olarak öğrenilmesinde kilit bir role sahip olan ilişkilendirme, matematiksel kavramların öğretiminde kazandırılması hedeflenen temel becerilerdendir (National Council of Teachers of Mathematics [NCTM], 2000). Bu becerinin kazandırılmasında öğretmenin öğretim ortamında kullanmış olduğu etkinlikler, materyaller, örnekler ve açıklamalar büyük bir role sahiptir. Bu nedenle öğrencilerin bir kavrama dair birbiriyle bağlantılı ilişkileri görebileceği ortamların tasarlanması oldukça önemlidir. Bu tür ortamların oluşturulması ve öğrencilere kazandırılması istenen hedefler öğretim programlarında ortaya konulmaktadır. Öğretim programlarındaki eksiklikler ve çağın gerektirdiği gelişmeler, zaman zaman programlarda yenilenme ve değişmelerin oluşmasına sebep olmaktadır.

Ülkemizde yakın zamanda matematik öğretim programlarında yapılan en köklü reform hareketi 2005 yılında olmuştur (Baki, 2008). 2005 yılında yapılan reform hareketi sonucunda matematiği öğrenme ve öğretmeye yönelik benimsenmiş olan anlayıș değișmiş ve bilginin bireyin aktif ürünü olduğu ve bilginin bireyden bağımsız olmadığı anlayışı benimsenmiş̧tir (Baki, 2008). Bu dönemde oluşturulan matematik öğretim programlarında konuların gerçek yaşamla ilişkili olmasının, somut deneyim ve sezgilerden yola çıkarak öğrencilerin kendi bilgilerini kendilerinin oluşturmalarının önemi vurgulanmıştır (Millî Eğitim Bakanlığı [MEB], 2007). Öğretim programlarında benimsenen yaklaşımın değişmesine paralel olarak programlarda yer alan konularda da değişiklikler yapılmıştır. Örneğin 2005 ilköğretim matematik öğretim programında ilk defa Öklid geometrisinden farklı bir geometri olan fraktal geometri yer almıştır (MEB, 2007). Fraktal kelimesi "düzensiz, kırıkl, karmaşık" anlamlarına gelen Latince "fractus" kelimesinden gelmektedir (Mandelbrot, 1983). Sezgisel anlamda bir fraktalı, belli oranlarda büyütülüp küçültülmüşs simetrik şekiller olarak tanımlayabiliriz (Fraboni ve Moller, 2008). Bunun yanında daha formal olarak bir fraktalı herhangi bir parçası kendine benzer olan özbenzerlik (self-similarity) özelliğine sahip bir şekil olarak ifade edebiliriz (Karakuş ve Baki, 2011). İlköğretim matematik öğretim programında fraktalların daha çok geometrik tekrarlamalar sonucunda oluşturulmas1 etkinliklerine yer verilmiştir. Fraktallar lise matematik öğretim programında ise 2010 yılında yer almıştır (MEB, 2010). Programda yansıma, öteleme ve dönme dönüşümleri yardımıyla fraktal şekillerin oluşturulması ve bu şekiller içerisinde yer alan çeşitli örüntülerin bulunması çalışmaları yapılmıştır (Karakuş ve Baki, 2011). Böylece hem ortaokul hem de lise matematik öğretim programlarında fraktal geometriye yer verilerek öğrencilerin geometri ile gerçek yaşam arasında ilişki kurmalarına ve farklı geometrileri inceleyerek Öklid geometrisi ile benzerlik ve farklılıklarını keşfetmelerine yardımcı olmaya çalışılmıştır. Benzer şekilde NCTM (1991) fraktalların matematik öğretim programlarında yer almasını önererek öğrencilerin matematiğe olan ilgi ve ihtiyaçlarının arttırılabileceğini ve matematik ile doğa arasında ilişkiler kurulabileceğini belirtmektedir.

Fraktalların hem geometrik hem de cebirsel olarak inşa edilebilir olmaları onların geometri ve matematiğin diğer alanları arasındaki ilişkileri incelemek için iyi bir uygulama alanı olduğunu göstermektedir. Buna karşın matematik öğretim programlarında yapılan güncellemeler doğrultusunda hem 2013 hem de 2017 matematik öğretim programlarında fraktal geometri konularına yer verilmemiştir. Her ne kadar fraktal geometri konuları mevcut matematik öğretim programlarında kazanım olarak yer almasa da birçok matematiksel özelliğin keşfedilmesinde ve bu keşif sürecinde farklı matematiksel bilgilerin işe koşulmasında büyük öneme sahiptir.

Fraktalların öğrencilerin hem matematiğin kendi içerisindeki kavramlarla hem de diğer disiplinler ve doğa ile farkı ilişkiler ve ilişkilendirmeler kurmalarına yardımcı olduğu alanyazında yapılan çalışmalarda ifade edilmektedir (Adams ve Aslan-Tutak, 2006; Bolte, 2002; Devaney, 2004; Fraboni ve Moller, 2008; Naylor, 
1999; Siegrist, Dover ve Piccolino, 2009; Vacc, 1999). Örneğin Fraboni ve Moller (2008) Sierpinski üçgeni ile ilgili hazırladıkları etkinliklerde öğrencilerin Sierpinski üçgenini ve özelliklerini incelerken matematiğgin farklı konuları arasında ilişkiler kurabileceklerini ve bu ilişkileri kurma sürecinde çeşitli keşifler yapabileceklerini belirtmektedir. Sierpinski üçgeni bir eşkenar üçgenin kenarlarının orta noktalarının birleştirilerek oluşan dört küçük üçgenden her defasında ortadaki üçgenin çıkarılması sonucu oluşmaktadır (Şekil 1).

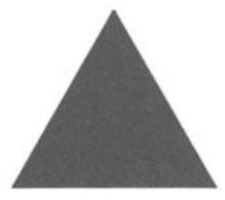

0. Adım

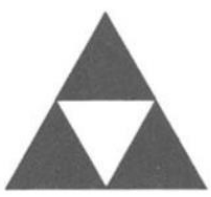

1. Adım

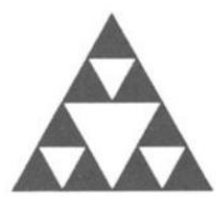

2. Adım

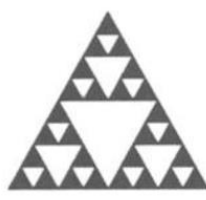

3. Adım

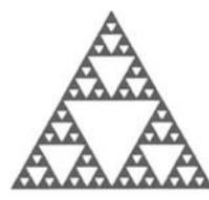

4. Adım

Şekil 1. Sierpinski üçgeninin oluşumunun adımları

Fraboni ve Moller (2008) öğrencilerin Sierpinski üçgeniyle yapacakları bir keşfin her tekrarlama aşamasında oluşan yeni üçgenlerin birbirleri ve başlangıçtaki üçgen ile aralarındaki ilişkiyi belirlemeleri şeklinde olabileceğini ifade etmektedir. Öğrencilerin bu ilişkiyi belirleyebilmeleri için "bir üçgenin iki kenar uzunluğunun orta noktasını birleştiren doğru parçası üçüncü kenara paralel ve uzunluğu bu kenarın yarısı kadardır" bilgisini kullanmaları gereklidir (Fraboni ve Moller, 2008, s.198). Bu bilgi sayesinde her tekrarlama adımında oluşan üçgenlerin birbirine eş ve bir önceki tekrarlama adımında oluşan üçgenlerin başlangıçtaki üçgene benzer olduklarını görebileceklerdir. Böylece öğrenciler Sierpinski üçgeniyle ilgili keşif yaparken aynı zamanda eşlik, benzerlik, paralellik ve "bir üçgenin iki kenar uzunluğunun orta noktasını birleştiren doğru parçası üçüncü kenara paralel ve uzunluğu bu kenarın yarısı kadardır" teoremi ile ilgili bilgileri arasında ilişkiler kurmaktadır. Benzer şekilde Naylor (1999) çalı̧̧masında Sierpinski üçgeninin çevresi ve alanının hesaplanmasıyla ilgili bir etkinlik sunmuştur. Naylor (1999) Sierpinski üçgeni oluşurken çıkarılan üçgen sayısı için 3'ün kuvvetleri şeklinde (birinci adımda 1, ikinci adımda 3 , üçüncü adımda $3^{2}=9$, dördüncü adımda $3^{3}=27 \mathrm{vb}$.) bir sayı örüntüsünün elde edilebileceğini belirtmektedir. Benzer bir örüntü her adımda oluşan küçük siyah üçgenler için de elde edilebilir. Bunun yanında Sierpinski üçgeninin çevresi $3\left(1+3 / 2+(3 / 2)^{2}+(3 / 2)^{3}+\cdots+(3 / 2)^{\mathrm{n}}\right)$ şeklinde raksak bir dizi ile ifade edilebilir. Bu dizi rraksak olduğundan Sierpinski üçgenin çevresi sonsuza gider. Buna karşın Sierpinski üçgeninin alanı sıfıra yakınsar. Bu etkinlik öğrencilerin Sierpinski üçgeninin çevresi ve alanını hesaplarken sayı örüntüleri, üslü sayılar, diziler ve limit kavramlarından yararlandıklarını göstermektedir. Bunun yanında Öklid geometrisindeki şekiller statik bir yapıya sahiptir. Yani Öklid şekillerinin belli bir çevresi ve alanı bulunmaktadır. Buna karşın Sierpinski üçgeninin ise sınırsız şekilde artan bir çevresi ve aynı zamanda sıfira doğru yaklaşan bir alanı bulunmaktadır. Bu tür sıra dışı durumlar hem öğrencilerin ilgisini çekmekte hem de öğrencilerin zihinlerinde yeni keşiflerin ortaya çıkmasına neden olabilecek "sonsuz çevreye sahip sıfır alanlı bir şekil nasıl olabilir?" ya da "bunun gibi başka şekiller de olabilir mi?" gibi sorular ortaya çıkarmaktadır.

\subsection{Kaos Oyunu (Chaos Game) Nedir?}

Fraboni ve Moller (2008) ile Naylor'un (1999) çalışmalarında olduğu gibi fraktallar sıklıkla kurallı geometrik tekrarlamalar sonucunda oluşturulmaktadır. Buna karşın rastgele olarak ifade edilen durumlar yardımıyla da fraktallar oluşturulabilmektedir. Fraktal oluşturmayı sağlayan bu durumlardan biri de kaos oyunudur. Kaos oyunu öğrencilerin yaşadıkları çevrede rastgele olarak ifade edilen birçok durum içerisinde aslında belli örüntü ve ilişkilerin bulunabileceği görmelerini sağlayan bir oyundur. Oyunun kuralı oldukça basittir: Üçgenin köşe noktaları olacak şekilde rastgele $\mathrm{A}$, $\mathrm{B}$ ve $\mathrm{C}$ noktaları ile yine rastgele bir $\mathrm{z}_{0}$ başlangıç noktası seçiniz. Bir zar atııı ve zarın üst yüzündeki sayı eğer,

1 ya da 2 gelirse $\mathrm{z}_{0}$ noktası ile A köşesi arasındaki uzaklığın orta noktasını bulup işaretleyiniz.

3 ya da 4 gelirse $\mathrm{z}_{0}$ noktası ile $\mathrm{B}$ köşesi arasındaki uzaklığın orta noktasını bulup işaretleyiniz.

5 ya da 6 gelirse $\mathrm{z}_{0}$ noktası ile $\mathrm{C}$ köşesi arasındaki uzaklığın orta noktasını bulup işaretleyiniz.

İşaretlediğiniz yeni noktayı $z_{1}$ ile gösteriniz. Artık yeni başlangıç noktanız $z_{1}$ oldu. Şimdi aynı işlemi $z_{1}$ noktası için tekrarlayınız. Tekrarlama işlemine devam ettiğinizde $z_{0}, z_{1}, z_{2}, z_{3}, \ldots$ noktalar dizisi elde edilir. Üç adım için oyun aşağıdaki gibi oynanabilir: $\mathrm{A}, \mathrm{B}$ ve $\mathrm{C}$ köşe noktaları arasında rastgele bir $\mathrm{z}_{0}$ başlangıç noktası belirleyiniz ve zarı atınız. Atılan zarın 3 geldiği kabul edilirse bu durumda $z_{0}$ ile $\mathrm{B}$ köşesi arasındaki uzaklığın tam orta noktası bulunur ve bu nokta $\mathrm{z}_{1}$ olarak işaretlenir. Zarın tekrar atıldığı ve bu kez de 1 geldiği kabul edilsin. Bu durumda $\mathrm{z}_{1}$ noktası ile A köşesi arasındaki uzaklığın tam orta noktası bulunur ve bu nokta $\mathrm{z}_{2}$ olarak işaretlenir. Benzer şekilde zar tekrar atılsın ve zarın 6 geldiği kabul edilirse bu durumda $\mathrm{z}_{2}$ noktası ile $\mathrm{C}$ köşesi arasındaki uzaklığın tam orta noktası bulunur ve bu nokta $z_{3}$ olarak işaretlenir (Şekil 2). 


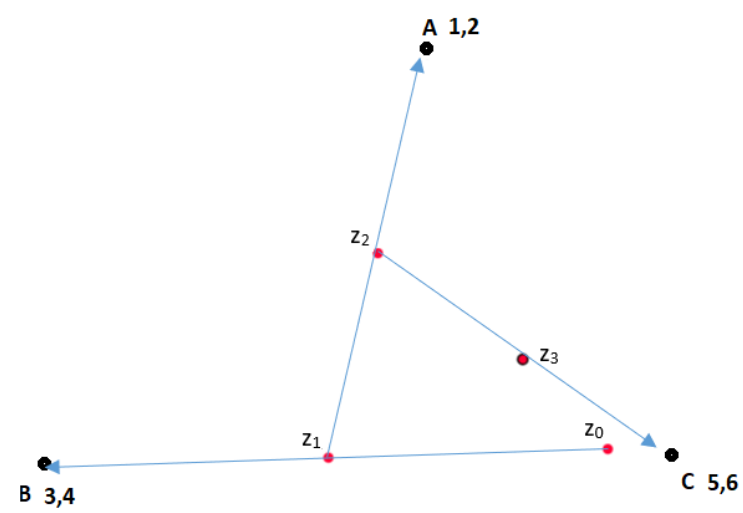

Şekil 2. Kaos oyunu sonucu oluşan noktalar dizisi

$\mathrm{Bu}$ şekilde zar atma işlemine devam edildiğinde $\mathrm{z}_{0}, \mathrm{z}_{1}, \mathrm{z}_{2}, \mathrm{z}_{3}, \ldots$ şeklinde sonsuz tane noktadan oluşan bir dizi elde edilir. Bu noktalar dizisiyle ilgili olarak akla aşağıdaki sorular gelebilir:

Noktaların oluşmasını sağlayan tekrarlama süreci gerçekten rastgele midir? ç1kar?

Zar binlerce kez atılsa ve her seferinde oluşan yeni noktalar işaretlense, sonuçta nasıl bir şekil ortaya

Kaos oyununda noktaların oluşmasını sağlayan tekrarlama süreci rastgeledir. Çünkü zar atıldığında köşe noktalarıyla eşleştirilen sayıların (1-2, A köşesi, 3-4, B köşesi ve 5-6, C köşesi) gelme olasılıkları birbirine eşittir. Bunun yanında $z_{0}$ başlangıç noktasının yeri de rastgele olarak belirlenmektedir. Hatta bu rastgele durumunu daha da arttırmak için tekrarlamalar sonucunda oluşan noktalar dizisinden ilk 10 nokta silinerek tekrarlama süreci yeniden başlatılabilir.

Yukarıda açıklandığı gibi kaos oyunu oynandığında sonuçta ne tür bir şeklin ortaya çıkacağı oldukça merak uyandırıcı bir durumdur. Oyunun rastgele olması ve noktalar dizisinin rastgele davranması sonucunda üçgenin içinde rastgele noktalar yığınının oluşacağı düşünülebilir. Benzer şekilde tekrarlama işlemine devam edildiğinde oluşan tüm noktaların üçgeni tamamen kaplayacağı, bir diğer olasılık olarak akla gelmektedir. Bunun yanında noktaların üçgenin içinde bir bölgede toplanacağı da bir başka durum olarak düşünülebilir. Aşağıda farklı sayıda tekrarlamalarda kaos oyunu sonunda oluşan şekiller gösterilmektedir (Şekil 3).

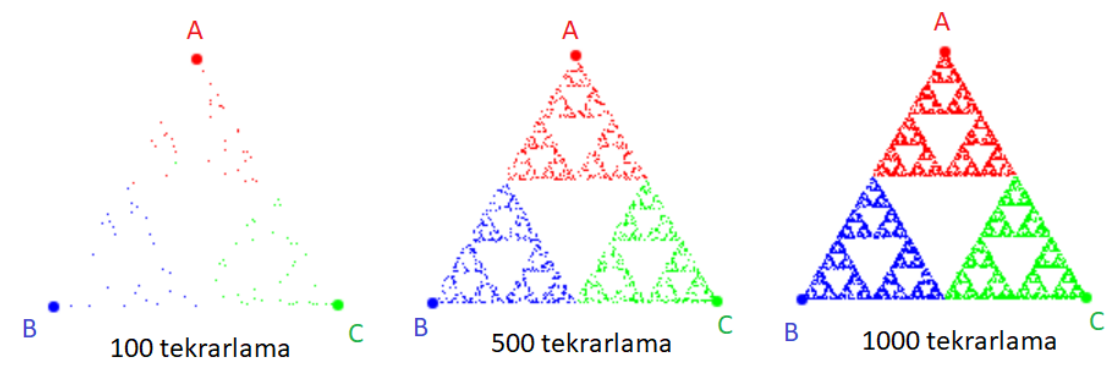

Şekil 3. Farklı tekrarlamalarda Kaos oyunu sonucu oluşan şekiller

Şekil 3'e göre tekrarlama sayısı arttıkça Kaos oyunu sonucu oluşan şekil git gide ünlü Sierpinski üçgeni fraktalına benzemektedir. Bu oldukça sıra dışı ve ilginç bir durumdur. Çünkü rastgele bir durum sonucunda düzgün bir geometrik şekil ortaya çıkmaktadır.

\subsection{Kaos oyunu sonucu niçin Sierpinski üçgeni oluşmaktadır?}

Kaos oyununa başlarken bir başlangıç noktası belirlenmektedir. Farz edelim ki başlangıç noktası $\mathrm{z}_{0}, \mathrm{ABC}$ üçgeninin tam ortasında olsun. Zar ilk kez atıldığında yeni oluşacak nokta $\mathrm{z}_{1}$, merkezde bulunan başlangıç noktası $\mathrm{z}_{0}$ ile üç köşe noktasından birisi arasındaki mesafenin yarısı kadar bir yerde bulunacaktır. Zarı attığımızda üstte gelen sayının 6 olduğunu varsayalım. Bu durumda $\mathrm{z}_{1}$ noktası Sierpinski üçgeninin birinci adımında oluşan 3 küçük üçgenden $\mathrm{C}$ köşesine yakın olan üçgenin tam ortasında yer alacaktır (Şekil 4). 

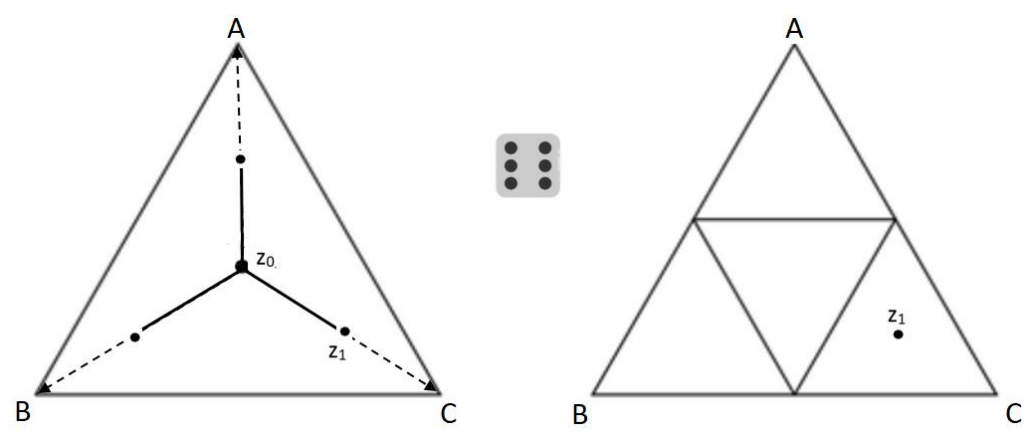

Şekil 4. Kaos oyununda $\mathrm{z}_{1}$ noktasının konumu

Benzer şekilde tekrarlama işlemine devam edildiğinde yeni oluşacak $z_{2}$ noktası $z_{1}$ ile üç köşe noktasından birisi arasındaki mesafenin yarısı kadar bir yerde bulunacaktır. Zarı attığımızda üstte gelen sayının 4 olduğunu farz edelim. Bu durumda $z_{2}$ noktası Sierpinski üçgeninin ikinci adımında oluşan 9 küçük üçgenden B köşesine yakın olan bir üçgenin tam ortasında yer alacaktır (Şekil 5).
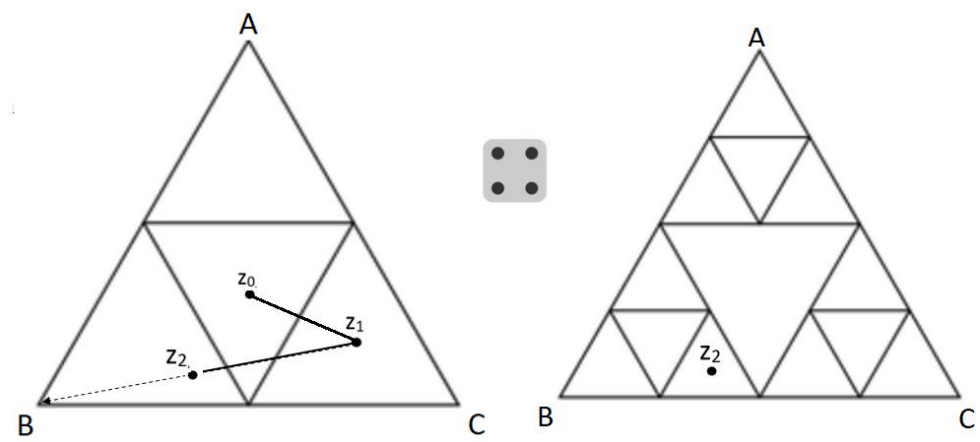

Şekil 5. Kaos oyununda $z_{2}$ noktasının konumu

Tekrarlama işlemine devam edildiğinde yeni oluşacak $\mathrm{z}_{3}$ noktası $\mathrm{z}_{2}$ ile üç köşe noktasından birisi arasındaki mesafenin yarısı kadar bir yerde bulunacaktır. Zarı attığımızda üstte gelen sayının 1 olduğunu farz edelim. Bu durumda $\mathrm{z}_{3}$ noktası Sierpinski üçgeninin üçüncü adımında oluşan 27 küçük üçgenden A köşesine yakın olan bir üçgenin tam ortasında yer alacaktır (Şekil 6).
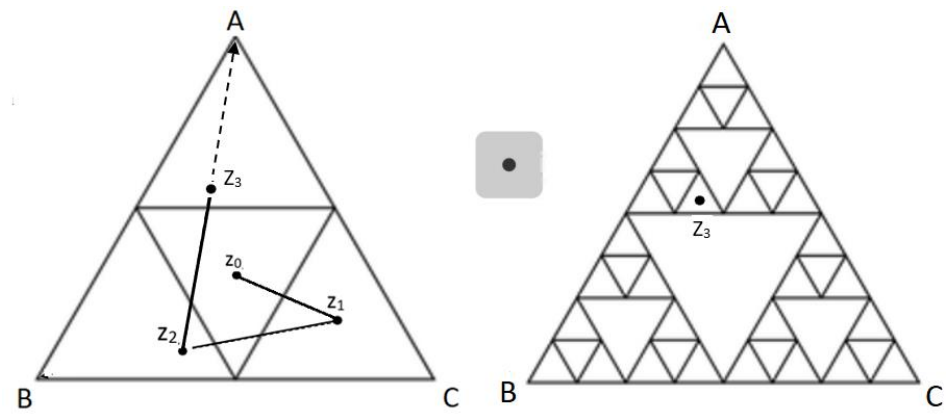

Şekil 6. Kaos oyununda $\mathrm{z}_{3}$ noktasının konumu

Benzer şekilde devam edildiğinde bir sonraki aşamada oluşacak $\mathrm{z}_{4}$ noktası Sierpinski üçgeninin dördüncü adımında oluşacak 81 küçük üçgenden biri içerisinde yer alacaktır. Böylece noktaların hareketi ile Sierpinski üçgeninin oluşum aşamalarında ortaya çıkan üçgenler birlikte düşünüldüğünde her bir zar atılması sonucunda oluşan $\mathrm{z}_{1}, \mathrm{z}_{2}, \mathrm{z}_{3}, \ldots$ noktaları Sierpinski üçgeninin tekrarlama adımlarında oluşan üçgenler içerisinde yer almaktadır. Sierpinski üçgeninde tekrarlamalar sonucunda oluşan üçgenler çok hızlı bir şekilde küçülüp mikroskobik hale geldiğinden bir süre sonra bu üçgenlerin içerisine düşen noktalarda Sierpinski üçgeninin kenarlarına çok yaklaşmakta ve onun kenarları gibi görünmektedir. Bu durum noktaların belli bir tekrarlama aşamasından sonra bir araya gelerek Sierpinski üçgeni şeklini oluşturmasına neden olmaktadır.

Kaos oyunu sayesinde öğrenciler hipotez kurma, ilişkilendirme, çıkarım yapma gibi becerilerini işe koşabilme imkanı elde etmekte ve olasılık, ölçme, örüntüler ve sayı dizileri gibi matematiksel kavramlarla ilgili farklı ilişkilendirmeler oluşturabilmektedirler (Devaney, 2004). Bu bağlamda bu çalışmanın amacı, öğrencilerin bu tür ilişkilendirmeler oluşturacakları etkinlikler hazırlamak ve bu etkinliklerin uygulanmasından yansımalara 
yer vererek öğrencilerin yapmış oldukları ilişkilendirmeleri belirlemektir. Bu amaca bağlı olarak bu çalışmanın problemleri;

- Geliştirilen fraktal etkinliklerine yönelik öğrencilerden elde edilen yansımalar nelerdir?

- Geliştirilen fraktal etkinlikleri öğrencilerin ne tür matematiksel ilişkiler oluşturmalarını sağlamaktadır?

şeklinde belirlenmiştir. Çalışmanın ilerleyen bölümlerinde öğrencilerin bu ilişkileri oluşturmalarına yardımcı olacak etkinliklere ve bu etkinliklere yönelik öğrencilerden alınan yansımalara yer verilmiştir. Bunun yanında etkinliklerin uygulanmasında öğretmenlere yol göstermesi açısından öneriler de sunulmuştur.

\section{Yöntem}

Çalışma kaos konusunda öğrencilerin matematiksel kavramlar arasında farklı ilişkilendirmeler oluşturacakları etkinlikleri tasarlaması ve bu etkinliklere yönelik ilköğretim matematik öğretmenliği birinci sınıf öğrencilerinin oluşturdukları ilişkilendirmeleri incelemesi nedeniyle bir özel durum çalışmadır. Özel durum çalı̧̧aları araştırmacıya çok özel bir konunun veya durumun üzerinde yoğunlaşarak incelenen özel durumları en ince ayrıntılarıyla tanımlama ve değişkenler arasındaki sebep-sonuç ilişkilerini açıklayabilme fırsatı vermektedir (McMillan ve Schumacher, 2014).

\section{1. Çalışma grubu}

Çalışmanın örneklemi, seçkisiz olmayan örnekleme yöntemlerinden uygun örnekleme yöntemi (convenience sampling) ile belirlenmiştir. Çalışmada uygun örnekleme yönteminin seçilmesinin nedeni zaman, para ve işgücü açısından var olan sınırlılıklar nedeniyle incelenecek grubun ulaşılabilir ve uygulama yapılabilir olmasıdır (McMillan ve Schumacher, 2014). Çalı̧̧ma grubunu İç Anadolu bölgesindeki bir devlet üniversitesinin eğitim fakültesi ilköğretim matematik öğretmenliği birinci sınıfında öğrenim gören 44 öğrenci oluşturmaktadırlar. $\mathrm{Bu}$ öğrencilerden 36'sı kadın ve 8'i ise erkektir. Öğrencilerin hiç biri kaos oyunu ile ilgili bir ön bilgiye sahip değildirler.

\subsection{Veri toplama aracı}

Bu çalışmada veriler öğrencilerin etkinliklere vermiş oldukları cevaplar ile odak grup görüşmelerinden elde edilmiştir. Çalışma için üç etkinlik geliştirilmiştir (Ek1-3). İlk etkinliğin amacı öğrencilerin rastgele bir süreç sonunda düzenli şekillerin oluşabileceğini görmelerini ve böylece kaotik düşünceye yönelik bir anlayış oluşturmalarını sağlamaktır. İkinci etkinliği amacı, kaos oyunu ve Sierpinski üçgeni arasında ilişki kurmalarına yardımcı olmaktır. Son etkinliğin amacı ise, öğrencilerin kaos oyununda atılan zarların gelme olasılı̆̆ının eşit olmasının Sierpinski üçgeninin oluşmasında önemli olduğunun farkına varmalarını ve hangi durumlarda kaos oyunu sonunda Sierpinski üçgeninin oluşup oluşmadığını belirlemelerini sağlamaktır. Etkinlikler Baki’de (2008) belirtilen etkinlik geliştirme basamakları gözönüne alınarak hazırlanmıştır. Etkinlikler hazırlandıktan sonra fraktallar konusunda bilgi sahibi olan doktorasını matematik eğitiminde yapan iki akademisyene sunularak uzman görüşü alınmıştır. Uzmanlar etkinliklerin genel olarak uygun olduğunu, ancak bazı küçük düzeltmelerin yapılabileceğini ifade etmişledir. Örneğin, Etkinlik 3'te verilen olasılık değerlerinin yanında öğrencilerin kendi değerlerini de girmelerinin daha uygun olacağı belirtilmiştir. Bu bağlamda Etkinlik 3 'te verilen olasılık değerlerinin altına öğrencilerin kendi değerlerini de yazıp incelemeleri için yer ayrılmıştır. Uzman görüşlerine göre etkinliklerde son düzenlemeler yapılarak uygulamaya geçilmiştir. Uygulama aşamasında ilk olarak öğrenciler 4'erli 11 gruba ayrılmıştır. Uygulama aşamasında her bir gruptan etkinlik kâğıtlarını yönergeler doğrultusunda doldurmaları ve elde ettikleri sonuçların nedenlerini açıklamaları istenmiştir. Veri toplamanın ikinci aşamasında ise çalışmaya katılan ve gönüllü olan 4 gruptaki toplam 16 öğrenci ile odak grup görüşmeleri yapılmıştır. Odak grup görüşmesi yapılmasının amacı, öğrencilerin etkinlik kâğıtlarında ortaya çıkmayan düşüncelerini ortaya çıkarmak, vermiş oldukları cevapların nedenleri derinlemesine incelemek ve cevapları üzerine tartışmalarını sağlamaktır. Odak grup görüşmelerinin odağını öğrencilerin etkinliklere vermiş oldukları cevaplar oluşturmaktadır. Bu nedenle öğrencilere "bu sonuca nasıl ulaştınız?", "Neler gözlemlediniz?", "Niçin bu cevabı yazdınız?" gibi öğrencilerin ne tür düşünme süreçleri yaşadıklarını ve ne tür ilişkilendirmeler oluşturduklarını ortaya çıkaracak sorulara yer verilmiştir. Odak grup görüşmeleri ses kaydına alınmış ve her bir görüşme ortalama 30 dakika sürmüştür.

\subsection{Etkinliklerin uygulanması süreci}

Etkinliklerin uygulama sürecine başlamadan önce öğrenciler dörderli gruplara ayrılmıştır. Öğrenciler etkinlikleri grup çalışması şeklinde yaparken araştırmacılardan biri de gruplar arasında dolaşarak öğrencilerin zorlandığ1 noktalarda ipucu niteliğindeki sorularla ve yönlendirmelerle öğrencilere rehberlik yapmıştır. Uygulamayı gerçekleştiren araştırmacı fraktallar konusunda deneyimli bir matematik eğitimcisidir. Araştırmacının fraktallar ve fraktalların öğretimi hakkında ulusal ve uluslararası hakemli dergilerde yer alan birçok çalışması bulunmaktadır. Etkinlikler 2 hafta boyunca haftada 2 ders saati olmak üzere toplam 4 ders saati uygulanmıştır. Etkinliklerin uygulanmasında bilgisayar laboratuvarı kullanılmış ve her gruba internete bağlı bir bilgisayar verilmiştir. İlk etkinlik 2 ders saati sürmüş ve öğrenciler şeffaf kağıt, kalem yardımıyla kaos oyununu 
oynamışlardır. Oyunun bu şekilde oynanmasının nedeni öğrencilerin noktaların hareketinin rastgele ve zar gelme olasılıklarının eşit olduğunu fark etmelerini sağlamaktır. Bunun yanında oyun sonunda ne tür şekillerin oluşacağ yönünde hipotez kurma, gözlem yapma ve çıkarsamada bulunma gibi becerilerini de bu süreçte işe koşmaları amaçlanmıştır. Öğrencilerden kağıt üzerinde oyunu oynadıktan sonra bilgisayarları açmaları istenmiş ve oyunu http://www.shodor.org/interactivate/activities/TheChaosGame/ web sitesi üzerinden oynamaları sağlanmıştır. Web sitesi kısa sürede daha fazla noktanın oluşmasına imkan verdiğinden daha doğru Sierpinski üçgeninin oluşmasını sağlamaktadır. İkinci etkinlik 1 ders saati sürmüş ve öğrencilerin Kaos oyunu ile Sierpinski üçgeni arasında ilişki kurmaları ve oyundaki noktaların hareketleri sonucunda Sierpinski üçgeninin nasıl oluştuğunu fark etmeleri amaçlanmıştır. Bu etkinlikte öğrencilerin örüntü bulma, tahmin ve çıkarsamada bulunma gibi becerilerini kullanmaları beklenmektedir. Son etkinlik ise 1 ders saati sürmüş ve yine http://www.shodor.org/interactivate/activities/TheChaosGame/ web sitesi kullanılmıştır. Bu etkinlikte zardaki sayıların farklı olasılık durumları web sitesindeki programda yerine yazılarak her bir olasılık durumunda oluşan şekilleri öğrencilerin gözlemlemesi sağlanmış ve Kaos oyununda Sierpinski üçgenin oluşum şartlarını bu gözlemler sonucunda öğrencilerin belirlemesi amaçlanmıştır.

\subsection{Verilerin analizi}

Öğrencilerin her bir etkinlik için vermiş oldukları cevaplar karşılaştırılmış ve öncelikle doğru ve yanlış olarak 2 kategoriye ayrılmıştır. Daha sonra her bir kategori kendi içerisinde incelenerek öğrencilerin süreç içerisinde yaşadıkları deneyimlerden yansımalar betimsel olarak sunulmuştur. Bu amaçla öğrencilerin vermiş oldukları cevaplardan doğrudan alıntılar yapılmıştır. Odak grup görüşmelerinden elde edilen veriler ise öğrencilerin etkinliklere vermiş oldukları cevapları destekleyecek şekilde betimsel olarak sunulmuştur. Elde edilen verilerin iç geçerliliğini sağlamak için odak grup görüşmelerinden elde edilen verilerin kontrolü katılımcı teyiti (Fraenkel ve Wallen, 2011) ile yapılmıştır. Ayrıca hem etkinliklere verilen cevaplar hem de odak grup görüşmelerinden elde edilen veriler kullanılarak veri çeşitlemesi (Cohen, Manion ve Morrison, 2000) yapılmıştır. Dış geçerliliği sağlamak için ise öğrencilerin cevaplarından ve odak grup görüşmelerinden alıntılara bulgular kısmında yer verilmiştir.

\section{Bulgular}

\section{1. "Kaos Oyunu" etkinliğinden yansımalar}

Bu etkinlik öğrencilerin rastgele bir süreç sonunda düzenli şekillerin oluşabileceğini görmelerini ve böylece kaotik düşünceye yönelik bir anlayış oluşturmalarını sağlamak amacıyla tasarlanmıştır. Etkinliğin ilk bölümü kağıt-kalem ortamında gerçekleştirilirken ikinci bölümü ise bilgisayar ortamında gerçekleştirilmiştir.

Oyunun öncelikle kağıt-kalem ortamında oynatılması öğrencilerin hem noktaların hareketini görmelerine hem de sürecin rastgele gerçekleştiğini fark etmelerine yardımcı olmaktadır. Kaos oyununda başlangıç noktasının rastgele belirlenmesi ve zar atışında gelen sayıların rastgele olması öğrencilerde süreç sonunda rastgele noktalardan oluşan bir üçgenin oluşabileceği yönünde bir algının oluşmasına neden olmaktadır. Etkinliği yapan tüm gruplar başlangıçta oyun sonucunda içi noktalarla kaplı olan bir üçgenin oluşacağını ifade etmişlerdir. Örneğin Grup 1 ile yapılan odak grup görüşmesinden elde edilen bulgular aşağıda sunulmuştur:

Araştırmacı: Oyunu oynarken başlangıçta nasıl bir şekil oluşacağını düşündünüz?

Grup 1: Tam belirgin olmasa da bir üçgen oluşacağını düşündük.

Araştırmacı: Niçin böyle bir şekil oluşacağını düşündünüz?

Grup1: A,B,C noktaları arasında rastgele bir nokta işaretledik. Zardan çıkan sayının ne olacağını bilmediğimizden önce rastgele bir şekil oluşur diye düşündük. Sonra hiçbir noktanın üst üste gelmediğini gördük ve tüm noktalar içeride kalıyordu. Bu nedenle içi noktalarla dolu bir üçgen oluşur diye düşündük.

Gruplar şeffaf kağıtlara yapmış oldukları işaretlemeleri (bkz. Şekil 7) üst üste koyup birleştirdiklerinde Tablo 1 'deki gözlemleri elde etmişlerdir.

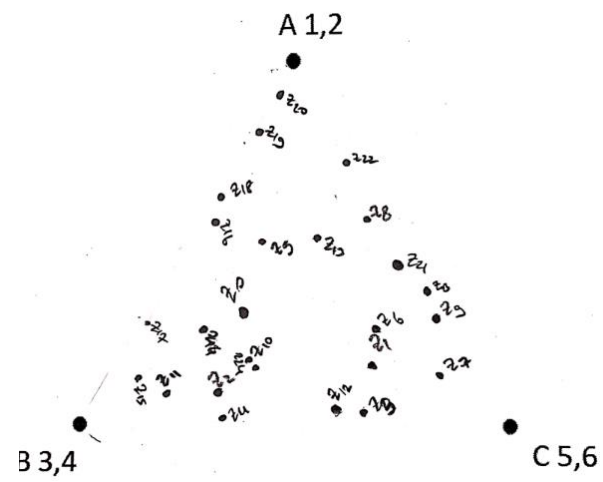

Şekil 7. Kaos oyunundaki noktalara yönelik bir öğrencinin işaretlemeleri 
Tablo 1. Grupların Kaos oyunu etkinliğindeki gözlemleri

\begin{tabular}{lc}
\hline Gözlemler & f \\
\hline Üçgenin ağırlık merkezinin olduğu yere çok fazla nokta düşmedi & 3 \\
Noktalar üçgenin ortası yerine belli yerlerde yoğunlaştı & 4 \\
Üçgenin orta kısmı boş kaldı & 8 \\
\hline
\end{tabular}

Tablo 1'e göre öğrencilerin oyundaki nokta sayısı arttığında bazı noktaların üçgenin iç bölgesine daha az düştüğünü ve kenarlara doğru noktaların yoğunlaştığını gözlemledikleri görülmektedir. Örneğin Grup 1 ile yapılan odak grup görüşmesinden elde edilen bulgular aşağıda sunulmuştur.

Araştırmacı: Grup arkadaşlarınızla kağıtlarınızı üst üste koyduğunuzda ne gözlemlediniz?

Grup1: Tam belirgin olmasa da üçgenin ortasında bir boşluk olduğunu fark ettik. Burada noktalar yoğun değildi.

Araştırmacı: Noktalar nerede yoğundu?

Grup1: Noktalar köşeleri oluşturan noktalarda kümeleniyordu. Belli yerlerde boşluklar kalıyordu.

Araştırmacı: Üçgenin ortasında niçin daha az nokta kalmış olabilir?

Grup1: Bunu grupça biz de düşündük. Aslında nedenini bilmiyoruz. Ancak her seferinde uzaklıkların yarısının alınmasıyla ilgili olabilir.

Araştırmacı: Niçin uzaklıkların yarısının alınmasıyla ilgili olabilir?

Grup1: Seçtiğimiz nokta üçgenin dışına çıkmıyor ve noktalar git gide birbirine yaklaşıyor. Her zar atışında noktalar arasındaki mesafe azalıyor. Bu da noktaların belli yerlerde toplanmasına neden oluyor gibi. Bundan dolayı olabilir. Emin değilim.

Yukarıdaki açıklamalar öğrencilerin oyun sonunda tamamen içi noktalarla dolu bir üçgenin oluşmayacağını, bazı yerlerde boşlukların oluştuğunu fark ettiklerini göstermektedir. Bu boşlukların oluşma nedenleri ile ilgili çıkarımlarının da olduğu görülmektedir. Web sitesinde Kaos oyununu oynadıklarında ise hızlı bir şekilde oyun sonunda Sierpinski üçgeninin oluştuğunu gözlemlemişlerdir. Bu bağlamda Grup 4 ile yapılan mülakat aşağıda sunulmuştur.

Araştırmacı: Web sitesinde oyunu oynadı̆̆ınızda hangi şekli elde ettiniz?

Grup 4: İçi boş üçgenlerden oluşan bir fraktal oluştu. İsmini siz söylemiş̧tiniz, Sierpinski üçgeni.

Araştırmacı: Bu şekil oluşunca ne düşündünüz?

Grup 4: Çok ilginçti. Böyle bir şeklin oluşacağını hiç düşünmemiştim.

Araştırmacı: Niçin bu fraktal oluşmuş olabilir?

Grup 4: Nedenini tam olarak bilmiyorum. Ortada boşluk olduğunu kağıt üzerinde noktaları işaretlerken biz de görmüştük. Ama bu kadar düzgün olacağını tahmin etmemiştim. Belki uzunluğun yarısının alınması olabilir.

Araştırmacı: Bu düşünceye sizi iten neden nedir?

Grup 4: Şekle dikkatlice bakınca iç içe üçgenler var ve hepsi kenarlarının orta noktasından birleştirilmiş. Oyunda da noktaların orta noktasını buluyorduk. Buradan olabilir diye düşündük.

Yukarıdaki açıklamalar öğrencilerin oyunun kuralı ile Sierpinski üçgeninin oluşum aşamaları arasında bir bağ olabileceğini gözlemlediklerini göstermektedir.

\section{2. "Kaos oyunu ile Sierpinski arasındaki ilişki" etkinliğinden yansımalar}

$\mathrm{Bu}$ etkinlik öğrencilerin muhakeme becerilerini kullanarak noktanın son yerini belirleme ve Sierpinski üçgeninin oluşum adımları ile zar atış sayısı arasında ilişki kurmalarına yönelik tasarlanmıştır. Etkinliğgin ilk bölümünde 8 grubun Sierpinski üçgenin oluşum adımları ile zar atış sayısı arasında doğru bir ilişki buldukları, 3 grubun ise bir ilişki bulamadıkları belirlenmiştir. Grup 3'ün elde etmiş olduğu ilişki Şekil 8'de sunulmuştur.

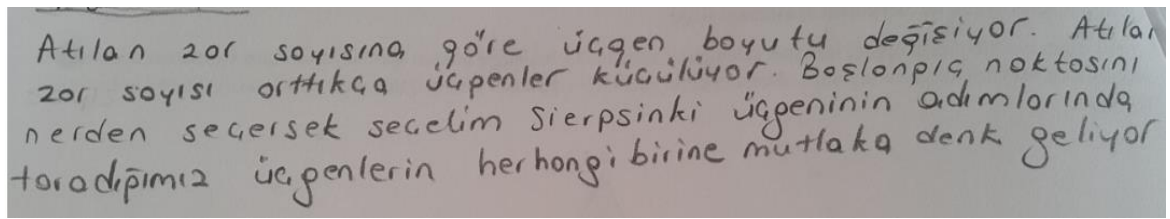

Şekil 8. Grup 3'ün elde ettiği ilişki

Bunun yanında farklı ilişkilerde elde eden gruplar bulunmaktadır. Örneğin Grup 5'in elde etmiş olduğu ilişki Şekil 9'da sunulmuştur. 


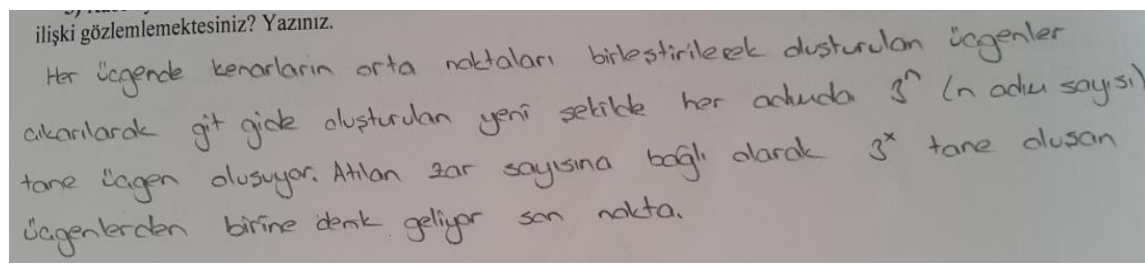

Şekil 9. Grup 5'in elde ettiği iliş̧ki

Etkinliğin ikinci bölümünde ise öğrencilerin noktanın bulunduğu son yere göre gelebilecek zarları tahmin etmeleri beklenmiş̧tir. 10 grubun tahminlerinin doğru sadece 1 grubun tahminin ise hatalı olduğu belirlenmiştir. Doğru tahminde bulunan Grup 4 ile yapılan mülakat aşağıda sunulmuştur:

Araştırmacı: Zarlarda gelen sayıları nasıl belirlediniz?

Grup 4: Tersine olarak tahmin etmeye çalıştık.

Araştırmacı: Biraz daha açıklar mısın? Nasıl?

Grup 4: Son nokta B köşesine yakın olduğundan 3. defa atılan zarın 3 ya da 4 olabileceğini düşündük. Sonra diğer nokta A noktasına yakın olmalı.

Araştırmacı: Niçin? Niye A noktasına yakın olmalı.

Grup 4: Aksi durumda 2. noktanın üçgenin dışına düşmesi gerekir ki bizim noktalarımız hep üçgenin iç kisminda.

Araştırmacı: Yani 2. nokta C'ye yakın olamaz.

Grup 4: Evet. Mesafenin orta noktasını aldığımızdan diğer durumda nokta dışarı düşüyor. Bu durumda 2. zar 1 ya da 2 gelmiş olabilir.

Araştırmacı: İlk zar ne olur o zaman?

Grup 4: Aynı mantıkla gittiğimizde ilk zar ise 5 ya da 6 olmalı yani ilk nokta da C noktasına yakın olmali.

Yukarıdaki ifadelerden öğrencilerin ölçme yapmadan eldeki verileri kullanarak bilinçli tahminler yaptıkları görülmektedir.

\section{3. "Kaos oyunu ve Olasılık" etkinliğinden yansımalar}

$\mathrm{Bu}$ etkinliğin amacı öğrencilerin Kaos oyununda atılan zardaki sayıların gelme olasılıklarının birbirine eşit olduğunu fark etmelerini ve hangi durumlarda Sierpinski üçgeninin oluştuğunu belirlemelerini sağlamaktır. Etkinliği yapan tüm gruplar Sierpinski üçgeninin oluşumunun zardaki sayıların gelme olasılıklarına bağlı olduğunu belirlemişlerdir. Örneğin Grup 7 ile yapılan mülakat aşağıda sunulmuştur.

Araştırmacı: Kaos oyununda zardaki sayıların gelme olasılıkları ile Sierpinski üçgeni arasında nasıl bir ilişki buldunuz?

Grup 7: Tam üçgeni oluşturmak istiyorsak her bir köşeye gelen sayıların gelme olasıllığı aynı olmalı. Yoksa bazen tam üçgen oluşmuyor.

Araştırmacı: Nasıl bir şekil oluşuyor?

Grup 7: Olasılı̆̆ düşük olan noktalarda üçgenin köşelerinin olduğu kısımlar daha silik, belli belirsiz oluyor, diğer kısımlar daha net oluyor.

Araştırmacı: Yine de bir Sierpinski üçgeni oluşuyor mu?

Grup 7: Evet oluşuyor, ama her bir köşesi aynı belirginlikte olmuyor, bazı yerleri daha silik oluyor.

Araştırmacı: Peki, hiç Sierpinski üçgeninin oluşmadığı bir durumla karşılaştııız mı?

Grup 7: Evet, mesela olasılığı 100 ya da 110 yaptığımızda Sierpinski üçgeni oluşmuyor.

Araştırmacı: Nasıl bir şekil oluşuyor?

Grup 7: 100 da tüm noktalar A köşesi üzerinde toplanıyor. Zaten hep aradaki mesafenin yarısını aldığımızdan her attığımızda hep 1 ya da 2 gelirse noktalar git gide A köşesine yaklaşır ve tek bir nokta gibi olur. $110 \mathrm{da}$ ise A ile B köşesi arasında bir doğru parçası oluşuyor. Yine mantık aynı.

Araştırmacı: O zaman Kaos oyunu sonucunda Sierpinski üçgeninin oluşması şartı nedir?

Grup 7: Tüm noktaların olasılığının aynı olması.

Yukarıdaki ifadeler öğrencilerin Kaos oyununda Sierpinski üçgeninin oluşması için zardaki sayıların gelme olasılıklarının birbirine eşit olması gerektiğini fark ettiklerini göstermektedir.

\section{Tartışma, Sonuç ve Öneriler}

$\mathrm{Bu}$ çalışmada öğrencilerin farklı matematiksel kavramlar arasında ilişkilendirmeler kuracăğ, farklı keşiflerde bulunacağ 1 fraktallar ile Kaos teori kapsamında etkinlikler geliştirilmiş ve bu etkinliklerin uygulanmasından yansımalara yer verilmiştir. Çalışmada farklı bir fraktal oluşturma yöntemi olarak Kaos oyununun ne olduğu ve oyun sonunda niçin Sierpinski üçgeni oluştuğu açıklanmışıtır. Ayrıca bu süreci farklı sınıf düzeyindeki öğrencilerinin yaşamalarına imkân verecek etkinlikler ile etkinliklerin uygulanmasını 
sağlayacak öğretmenlere yönelik açıklamalar geliştirilmiştir. Bunun yanında etkinliklerin uygulanmasından örneklere yer verilmiş ve öğrencilerin etkinlikler sonucunda ne tür ilişkilendirmeler kurdukları ve elde ettikleri sonuçlardan yansımalar sunulmuştur. Böylece etkinliklerin uygulanabilirliği de ortaya konulmaya çalışılmıştır.

İlk etkinlik öğrencilerin Kaos teori ile ilgili algı oluşturmalarına yönelik hazırlanmıştır. Bu etkinlikte öğrencilerden rastgele olarak görülen bir olayda belli bir düzenin olabileceğini fark etmeleri amaçlanmıştır. Bu kapsamda öğrenciler etkinlik boyunca gözlem yapma ve hipotez kurma becerilerini sıklıkla kullanmışlardır. Öğrencilerin oyunun başlangıcında başlangıç noktasının rastgele seçilmesi ve zar atışında gelen sayıların rastgele olması nedeniyle ortaya çıkacak şeklin de rastgele noktalardan oluşan bir şekil olabileceği yönünde bir iddiaları olmuştur. Ancak daha sonra yapmış oldukları gözlemler bu hipotezlerinin değişmesine ve üçgenin iç bölgesine ya da ağırlık merkezine nokta düşmemektedir gibi yeni iddiaların oluşmasına neden olmuştur. Bu bağlamda ilk etkinliğin öğrencilerin hipotez kurma, gözlem yapma ve çıkarsamada bulunma gibi becerilerini işe koşmalarına imkan verdiği söylenebilir. Bunun yanında bu etkinliğin öğrencilerin tekrarlamalı bir süreç içerisinde ölçme yaparak noktaların hareketini izleme ve bu süreç sonunda çıkarsamada bulunmalarına da yardımcı olduğu görülmektedir. Yenilenen matematik öğretim programında da öğrencilerin matematiğin konuları arasında hipotez kurma, gözlem yapma, ilişkilendirme ve çıkarım yapma gibi becerilerini kullanacağı ortamların hazırlanmasına ve örneklerin verilmesine vurgu yapılmaktadır (Milli Eğitim Bakanlı̆̆ alanyazında yapılan çalışmalarda (Adams ve Aslan-Tutak, 2006; Bolte, 2002; Devaney, 2004; Fraboni ve Moller, 2008; Karakuş, 2015, 2016; Naylor, 1999; Siegrist, Dover ve Piccolino, 2009; Vacc, 1999) fraktalların öğrencilerin matematiğin benzerlik, logaritma, örüntüler ve limit gibi farklı konuları arasında ilişkiler kurmasına yardımcı olduğu ve hipotez kurma, ilişkilendirme ile çıkarım yapma gibi becerilerini işe koşmalarını sağladığ ifade edilmektedir. Bu çalışmadan elde edilen sonuçlar alanyazındaki çalışmaların sonuçları ile benzerlik göstermektedir. Geliştirilen ilk etkinlikte Kaos oyunu sadece üç nokta için oynatılmıştır. Bu etkinlik farklı sayıdaki nokta ile yeniden tasarlanabilir. Bunun yanında etkinliğin sonunda öğrencilere farklı sayıdaki nokta için oyunun oynanması durumunda ne tür şekillerin oluşabileceği gibi yeni iddia ve çıkarsamalar oluşturacakları sorular eklenebilir. Ayrıca noktaların hareketinde $1 / 2$ oranı yerine $1 / 3$ ya da $1 / 4$ gibi farklı oranlar için oyun yeniden oynatılabilir. Bu durumları içeren etkinlikler ve bu etkinliklere yönelik öğrencilerden alınacak yansımalar ileriki çalışmalarda incelenebilir.

Amerikan Ulusal Matematik Öğretmenleri Konseyi (NCTM, 2006) cebirsel düşünmenin gelişiminde öğrencilerin farklı örüntüler tanımaları, oluşturmaları ve genellemelerinin öneminden bahsetmektedir. Bu çalışmada oluşturulan ikinci etkinlik öğrencilerin bu tür örüntüler keşfetmelerine imkan vermektedir. Çalışmaya katılan hemen hemen her grup Sierpinski üçgeninin oluşum aşamaları ile atılan zar sayıları arasında doğru ilişkiler kurmuştur. Bunun yanında atılan zar sayıları ile Sierpinski üçgeninde oluşan üçgen sayıları gibi farklı örüntüler de ortaya çıkmıştır. Bu durum tasarlanan etkinliklerin öğrencilerin farklı örüntüler bulmalarına yardımcı olabilecek bir potansiyele sahip olduğunu göstermektedir. Bunun yanında ikinci etkinlik tıpkı birinci etkinlikte olduğu gibi öğrencilerin tahmin yapma ve çıkarsamada bulunma becerilerini de kullanmalarına imkan vermektedir. Özellikle noktanın son yerinin verilip başlangıçta bulunduğu yerin sorulduğu bölüm öğrencilerin bu becerilerini kullanmalarını sağlamaktadır. Alan yazında yer alan bazı çalışmalarda da (Adams ve Aslan-Tutak, 2006; Fraboni ve Moller, 2008; Naylor, 1999; Vacc, 1999; Karakuş, 2015) öğrencilerin Sierpinski üçgeninde oluşan üçgen sayısı ile Sierpinski üçgeninin çevresi ve alanıyla ilgili üslü sayılar, diziler ve limit kavramlarını kullanarak çeşitli genellemelere ulaşabildikleri ifade edilmektedir. Bu bağlamda bu çalışmadan elde edilen sonuçlar alanyazında yapılan çalışmaların sonuçlarıyla örtüşmektedir.

Son etkinliğin amacı, öğrencilerin Kaos oyununda atılan zarların gelme olasılığı ile Sierpinski üçgeninin oluşumu arasında ilişki kurmalarına yöneliktir. Etkinlik sonucunda öğrenciler Sierpinski üçgeninin oluşumunun zarlardaki sayıların gelme olasılıklarının eşit olması durumuna bağlı olduğu sonucunu elde etmişlerdir. Bunun yanında farklı olasılık durumlarında ne tür şekillerin oluştuğunu ve hangi durumlarda Sierpinski üçgenin oluşmadığını gözlemleme imkanı elde etmiş̧lerdir. Alan yazında yapılan çalışmalar (Gürbüz, 2006; Işık ve Özdemir, 2014; Memnun, 2007) olasılık konularının öğretiminde somut materyal ve çalışma yapraklarının kullanılmasının öğrencilerin anlamlı öğrenmeler oluşturmalarına ve akademik başarılarına olumlu yönde katkılarının olduğunu göstermektedir. Bu çalışmada geliştirilen etkinliklerden elde edilen yansımalar etkinliklerin öğrencilerin olasılık konuları ile ilgili anlamalarına yardımcı olabileceğini göstermektedir. Bu bağlamda geliştirilen etkinliklerin öğrencilerin anlamlı öğrenme ve akademik başarıları üzerindeki etkileri ileriki araştırmalarda incelenebilir.

Kaos oyunu öğrencilerin sadece Sierpinski üçgenini oluşturmalarına yardımcı olmamaktadır, aynı zamanda öğrencilerin rastgele durumlar sonucu düzenli/kurallı örüntülerin oluşacağını fark etmelerine ve böylece dinamik sistemler ve kaos teoriye yönelik bir temel hazırlamaktadır. Son yıllarda dinamik sistemler, bulanık mantık ve kaotik yapılar matematik alanında sıklıkla tartışılan konuların başında gelmektedir. Hazırlanan bu etkinlikler öğrencilerin ileriki yaşamlarında bu konulara ilgi göstermelerine ya da bu konularla çalışmalarına imkân sağlayabilir. Zira matematik eğitiminin genel amaçlarından biri de geleceğin matematikçilerini yetiştirmektedir (Baki, 2008). Rastgele bir durum sonucunda düzenli şekillerin ortaya çıkması her sınıf düzeyindeki öğrencinin ilgisini çekecektir. Bu tür etkinlikler öğrencilerin matematik dersine yönelik ilgi ve tutumlarını pozitif yönde 
etkileyecektir. Literatürde yapılan çalışmalarda da derste kullanılacak etkinlik ve materyallerin öğrencilerin matematik dersine yönelik ilgileri üzerinde etkileri olduğu vurgulanmaktadır (Ünlü, 2007; Yurtbakan, Aydoğdu İskenderoğlu ve Sesli, 2016). Bu bağlamda tasarlanan bu etkinliklerin öğrencilerin matematik dersine yönelik ilgi ve tutumları üzerindeki etkileri ileriki çalışmalarda incelenebilir. Çalışmada hazırlanan etkinliklerle çalışan öğrenciler olasılık, sayı dizileri, örüntüler ve ölçüm gibi birçok farklı matematiksel kavram arasında ilişkiler kurma firsatı elde etmektedirler. NCTM'de (2000) öğrencilerin matematiksel kavramları anlamlı öğrenmeleri için uygun etkinlik, materyal ve örneklere sahip ortamlarda çalışmasının önemi vurgulanmaktadır. Bu bağlamda hazırlanan etkinliklerin öğrencilerin matematiksel kavramlar arasında farklı ilişkilendirmeler yapma potansiyeline sahip olduğu söylenebilir.

$\mathrm{Bu}$ çalışmada da öğrencilerin örüntüler, olasılık, ölçme ve sayı dizileri konularında ilişkiler kuracağı etkinliklere yer verilmiştir. Bunun yanında matematik öğretim programlarında bilgi ve iletişim teknolojilerinin (BİT) derslere entegre edilmesinin önemi vurgulanmıştır (MEB, 2018a; 2018b). Ülkemizdeki matematik öğretimi göz önüne alındığında, genelde öğretmen odaklı ve tahta başında geleneksel bir anlayışın benimsendiği söylenebilir (Gür, 2002). Matematik konularının öğretiminde, genellikle konularla ilgili kurallar ve özellikler, sunuş yöntemi ile verilmekte, tahtaya yazılan çizimler yardımıyla konuları öğretimi gerçekleştirilmektedir. Amerikan Ulusal Matematik Öğretmenleri Birliği (NTCM, 2000) de, okul matematiğinde somut materyaller, çizimler ve bilgi iletişim teknolojilerinin kullanılmasının önemini vurgulamaktadır. Bu çalışmada tasarlanan etkinliklerde öğretim amaçlı hazırlanmış web sitesi uygulamalarına yer verilmiştir. Böylece öğrencilerin bu ilişkileri kurarken teknolojiden de yararlanması sağlanmıştır. Bu bağlamda tasarlanan etkinliklerin matematik derslerine BİT'lerinin entegre edilmesine katkı sağlayacağı söylenebilir.

\section{Kaynaklar / References}

Adams, T. L., \& Aslan-Tutak, F. (2006). Serving up Sierpinski! Mathematics Teaching in the Middle School $11(5), 248-251$

Baki, A. (2008). Kuramdan uygulamaya matematik eğitimi. Ankara: Harf Eğitim Yayınları.

Bolte, L. A. (2002). A snowflake project: Calculating, analyzing, and optimizing with the Koch snowflake. Mathematics Teacher, 95(6), 414-419.

Cohen, L., Manion, L., \& Morrison, K. (2000). Research methods in education 5th edition. London: RoutledgeFalmer.

Devaney, R., L. (2004). Fractal patterns and chaos games. Mathematics Teacher, 98(4), 228-233.

Fraboni, M., \& Moller, T. (2008). Fractals in the classroom. Mathematics Teacher, 102(3), 197-199.

Fraenkel, J. R., Wallen, N. E., \& Hyun, H. H. (2011). How to design and evaluate research in education. New York: McGraw-Hill.

Gürbüz, R. (2006). Olasılık kavramlarının öğretimi için örnek çalışma yapraklarının geliştirilmesi. Çukurova Üniversitesi Ĕ̈itim Fakültesi Dergisi, 31(1), 111-123.

Işık, A. ve Özdemir, G. (2014). Çalışma yapraklarıyla olasılık öğretiminin öğrenci başarısına etkisi. Middle Eastern \& African Journal of Educational Research, 12, 4-16.

Karakuş, F. ve Baki, A. (2011). İlköğretim 8. sınıf matematik öğretim programı ve ders kitaplarının fraktal geometri konusu kapsamında değerlendirilmesi. İlkögretim Online, 10(3), 1081-1092.

Karakuş, F. (2015). Investigation into how 8th grade students define fractals. Educational Sciences: Theory and Practice, 15(3), 825-836.

Karakuş, F. (2016). Pre-service teachers' concept images on fractal dimension. International Journal for Mathematics Teaching and Learning, 17(2), 1-17.

Mandelbrot, B. B. (1983). The fractal geometry of nature. New York: W. H. Freeman and Co.

McMillan, J. H., \& Schumacher, S. (2014). Research in education: Evidence-based inquiry (7th ed.). Boston: Pearson Education Inc.

Memnun, D. S. (2007). Permütasyon ve olasılık konularının aktif öğrenme ile öğretiminin öğrenci başarısına etkisi. NWSA: Education Sciences, 2(4), 398-412.

Milli Eğitim Bakanlığ̣ [MEB]. (2007). Ilköğretim matematik dersi 6-8. sinıflar öğretim programı ve kılavuzu. Ankara: Milli Eğitim Bakanlığı.

Milli Eğitim Bakanlığı [MEB]. (2010). Ortaöğretim geometri dersi 9-10. sinıflar öğretim programı. Ankara: MEB-Talim Terbiye Başkanlığı Yayınları

Milli Eğitim Bakanlığı [MEB]. (2018a). Matematik dersi ögretim programı (ilkokul ve ortaokul 1, 2, 3, 4, 5, 6, 7 ve 8. sinıflar). Ankara: Milli Eğitim Bakanlığg1.

Milli Ĕ̆itim Bakanlı̆̆1 [MEB]. (2018b). Ortä̈̆gretim matematik dersi (9, 10, 11 ve 12. sinıflar) ögretim programı. Ankara: Milli Eğitim Bakanlığ 1 .

National Council of Teachers of Mathematics [NCTM]. (1991). Professional standards for teaching mathematics. Reston, VA: NCTM.

National Council of Teachers of Mathematics [NCTM]. (2000). Principles and standards for school mathematics. Reston, VA: NCTM. 
National Council of Teachers of Mathematics [NCTM]. (2006). Curriculum focal points for prekindergarten through grade 8 mathematics. A guest for coherence. Reston VA: National Council of Teachers of Mathematics, Inc.

Naylor, M. (1999). Exploring fractals in the classroom. Mathematics Teacher, 92(4), 360- 366.

Siegrist, R., Dover, R., \& Piccolino, A. (2009). Inquiry into fractals. Mathematics Teacher, 103(3), $206-212$.

Skemp, R. R. (1976). Relational understanding and instrumental understanding. Mathematics Teaching, 77(1), 20-26.

Ünlü, E. (2007). İlköğretim okullarındaki üçüncü, dördüncü ve beşinci sınıf öğrencilerinin matematik dersine yönelik tutum ve ilgilerinin belirlenmesi. Dumlupınar Üniversitesi Sosyal Bilimler Dergisi, 19, 129-148.

Vacc, N. N. (1999). Exploring fractal geometry with children. School Science and Mathematics, 99(2), 77-83.

Van de Walle, J. A., \& Karp, K. S. Bay-Williams, J. M. (2012). Elementary and middle school mathematics: Teaching developmentally (8th ed.). Boston: Pearson.

Yurtbakan, E, Aydoğdu-İskenderoğlu, T. ve Sesli, E. (2016). Sınıf öğretmenlerinin öğrencilerin matematik dersindeki başarılarını arttırılma yolları konusundaki görüşleri. Ondokuz Mayıs Üniversitesi Eğitim Fakültesi Dergisi, 35(2), 101-119. 